\title{
In Vitro Propagation of the Amazonian Medicinal Plant Guayusa (llex Guayusa) and Effects of Light in the Growth and Development of this Shade Tolerant Plant
}

Sofia D. Carvalho ( $\square$ sofiadomcarvalho@gmail.com )

Universidad San Francisco de Quito https://orcid.org/0000-0002-8785-3449

\section{Mayra Ortega}

Universidad San Francisco de Quito

\section{Miguel Orellana}

Universidad San Francisco de Quito

\section{Michelle Rodríguez}

Universidad San Francisco de Quito

\section{Kevin M. Folta}

University of Florida Institute of Food and Agricultural Sciences

\section{Maria Torres}

Universidad San Francisco de Quito

\section{Research Article}

Keywords: Guayusa was propagated on mWPM medium supplemented with activated charcoal, Spontaneous root development occurred in most shoots, Light quality affected plant development, green and farred light could influence root growth.

Posted Date: May 6th, 2021

DOl: https://doi.org/10.21203/rs.3.rs-478388/v1

License: (c) (i) This work is licensed under a Creative Commons Attribution 4.0 International License. Read Full License

Version of Record: A version of this preprint was published at Plant Cell, Tissue and Organ Culture (PCTOC) on July 18th, 2021. See the published version at https://doi.org/10.1007/s11240-021-02142-y. 
4 Sofia D. Carvalho ${ }^{\mathrm{a}}$, Mayra Ortega ${ }^{\mathrm{a} 1}$, Miguel Orellana ${ }^{\mathrm{a}}$, Michelle Rodríguez ${ }^{\mathrm{a}}$, Kevin M. Folta ${ }^{\mathrm{b}}$, Maria de Lourdes

5 Torres $^{\mathrm{a}^{*}}$

6

$7 \quad{ }^{a}$ Laboratorio de Biotecnología Vegetal, Colegio de Ciencias Biológicas y Ambientales, Universidad San

8 Francisco de Quito, Quito, Ecuador

$9 \quad{ }^{\mathrm{b}}$ Horticultural Sciences Department, University of Florida, Gainesville, FL, USA

10

$11{ }^{1}$ Authors contributed equally to this work.

12

13 * Correspondence:

14 Maria de Lourdes Torres

15 E-mail: 1torres@usfq.edu.ec

16 Orcid-ID: 0001-7207-4568 


\section{$1 \quad$ Keywords}

2 Ilex guayusa, axillary bud culture, light regulatory effects, Amazon region, indigenous groups.

\section{Abstract}

5 Guayusa (Ilex guayusa) is an endemic plant from the Amazon with potential medicinal applications. Indigenous

6 people are familiar with such applications and use guayusa based on ancestral knowledge. There is a growing

7 interest in guayusa-based products in urban areas of Ecuador and internationally. The supply cannot meet the

8 demand. Currently, traditional practices are used for guayusa growth and the potential use of the protected forest

9 is foreseen. This work describes a protocol for the in vitro propagation of guayusa, a sustainable solution to

10 generate high quality plants in reduced space. Stakes obtained from stems were used as explants. Chemical

11 sterilization with ethanol and sodium hypochlorite resulted in $100 \%$ surface-sterilized stakes. The growth

12 medium mWPM resulted in favorable outcomes regarding shoot development and elongation, as well as rooting.

13 Supplementation with activated charcoal resulted in reduced browning during the elongation phase. The majority

14 of shoots were able to develop roots spontaneously. Medium supplementation with the auxin indole-3-butyric

15 acid, IBA, may be considered when rooting does not occur spontaneously. Acclimatization was performed in soil.

16 The protocol was tested under different light spectra, revealing that guayusa growth is affected by light quality.

17 The photobiology of this shade tolerant plant requires further characterization, but the data uncovered a potential

18 role for green and far-red light in root development.

20 Key message

21 Guayusa was propagated on mWPM medium supplemented with activated charcoal. Spontaneous root 22 development occurred in most shoots. Light quality affected plant development, green and far-red light could 23 influence root growth.

26 AC: activated charcoal

27 B: blue light

28 FR: far-red light

29 G: green light 
HY5: ELONGATED HYPOCOTYL 5

2 IBA: indole-3-butyric acid

3 LED: light-emitting diode

4 MS: Murashige \& Skoog

5 mWPM: modified Woody Plant Medium

6 NAA: 1 -naphthaleneacetic acid

$7 \quad$ R: red light

8 STN: shoot tip necrosis

$9 \quad$ W: white light

10 WPM: Woody Plant Medium

\section{Introduction}

13 The Amazon rainforest is home to thousands of medicinal plants. Indigenous groups rely on ancestral 14 knowledge to use and propagate these plants for diverse therapeutic uses (Thomas et al. 2011; Innerhofer and 15 Bernhardt 2011; Giovannini 2015; Robles Arias et al. 2020). A considerable part of the general population of 16 countries within the Amazonian region also depends on herbal medicine for basic healthcare needs (Leone et al. 17 2007), and there is a growing interest from the pharmaceutical and food industries and from international 18 consumers to benefit from Amazonian plants (Gu et al. 2014). Cultivation practices remain however often 19 primitive and result in low yields. Increasing areas of forestland are used, which disturbs wildlife habitats and

20 poses a threat to the delicate and essential Amazonian ecosystem (Thomas et al. 2011). The development of

21 sustainable and efficient cultivation practices is critical to respond to the growing demand of medicinal plants and 22 simultaneously protect the Amazonia.

23 Guayusa (Ilex guayusa) is an evergreen dioecious tree from the upper Amazon in Ecuador, Peru and Colombia. It

24 is largely cultivated by indigenous groups and the most significant medicinal plant among the Kichwa

25 (Innerhofer and Bernhardt 2011). Guayusa leaves have antioxidant, antibacterial, anti-parasitic, and anti26 inflammatory properties (Kapp et al. 2016; Radice, M. et al. 2017; García-Ruiz et al. 2017; Pardau et al. 2017;

27 Gamboa et al. 2018; Gan et al. 2018; Chianese et al. 2019). They are used for many purposes, such as, boosting 28 energy and alertness, protection against snakebites, treatment for gastritis, or inducer of female fertility. These 
1 traditional therapeutic applications correlate with biochemical analyses of guayusa leaves that have identified the

2 presence of several secondary metabolites, such as theobromine and other alkaloids, flavonoids and other

3 phenolic compounds, as well as caffeine (Kapp et al. 2016; García-Ruiz et al. 2017; Pardau et al. 2017; Gan et al.

4 2018; Chianese et al. 2019).

5 Indigenous groups typically propagate guayusa in household gardens called "chakras", together with other

6 medicinal and edible plants and subsistence crops (Perreault 2005; Krause and Ness 2017). "Chakra" production

7 is a marker of cultural identity for indigenous groups and traditionally ensured household food security.

8 Nowadays some indigenous groups in Ecuador have established small organizations that use "chakra" production

9 for the commercialization of guayusa leaves together with other products (Wiñak Association 2020). A few

10 companies, such as Runa and Wa, acquire these guayusa leaves to produce and sell tea-based products and other

11 beverages. Indigenous groups in Ecuador are amongst the most vulnerable people in poverty and such activity

12 has helped them reaching better economic status (El Comercio 2018; Fundación Futuro Latinoamericano and

13 Grupo FARO 2020). However, the expansion of cultivated areas in the forest may not be sustainable. It has been

14 estimated that over 2,000 hectares of the Amazonia are being cultivated with guayusa, which poses a burden on

15 the forest (El Comercio 2018). The continuous preference of the same cultivars over other varieties may also

16 negatively impact ecosystems and their sustainability (FAO 2008; Isbell et al. 2017).

17 The practice of in vitro propagation is an alternative and sustainable solution to replace greenhouse or outdoor

18 nursery operations; optimal protocols can yield high numbers of vegetative propagules using less space and fewer

19 resources. It allows the conservation of plant genetic diversity by not converting natural space to propagation

20 nursery space (Yokoya and Yoneshigue-Valentin 2011; Opabode 2017; El-Sherif 2019). It can be a solution to

21 propagate plants with reduced seed fertility, such as is the case for guayusa (Dolce et al. 2011; Dueñas et al.

22 2016). Plant in vitro propagation is performed in indoor conditions, where environmental factors that affect plant

23 growth, yield and quality can be controlled with precision. Light is an environmental factor of particular interest

24 in such approaches. Light regulates gene expression, plant growth, hormone signaling, physiology and

25 metabolism at different stages of development (Wu 2014; Gelderen et al. 2018b; Wang et al. 2019). From UV to

26 far-red light, discrete wavelengths are sensed by plant photoreceptors that activate and regulate specific internal

27 pathways (Fankhauser and Christie 2015; Galvão and Fankhauser 2015; Legris et al. 2019; Tripathi et al. 2019;

28 Yadav et al. 2020). The usage of LEDs in indoor conditions allows for the design of specific light conditions to 
modulate plant growth and quality (Darko et al. 2014; Landi et al. 2020). Fundamental knowledge on plant

2 photobiology was first explored and described in Arabidopsis thaliana (Paik and Huq 2019). While some of these

3 mechanisms translate to crops, it has been evident that some light regulatory effects are plant species-specific

4 (reviewed in Carvalho and Folta 2014). It is important therefore that plant response to light is individually

5 assessed on case-by-case studies. The role of light in the growth and development of guayusa has not been

6 described. This plant typically grows in the dense Amazonian forest, where the solar spectrum is enriched in

7 green and far-red light, compared to full sunlight conditions (Ballaré and Pierik 2017). The molecular

8 mechanisms behind the shade tolerance of guayusa are unknown. Unraveling such mechanisms can allow the

9 development of strategies to facilitate the indoor propagation of this plant and to improve its quality, namely in

10 the accumulation of leaf secondary metabolites.

11 The current work describes an in vitro protocol for the propagation of guayusa. We couple plant tissue culture

12 with specific light regimen to test the hypothesis that guayusa growth and quality can be manipulated with light.

13 The usage of specific light treatments revealed novel details of the photobiology of guayusa and specific roles of

14 light during the development of this plant. Our results highlight the importance of conclusive photobiological

15 assays in order to understand the effect of light on plant physiology and optimize the growth and cultivation of

16 individual species.

\section{Materials and Methods}

Overview of the protocol

21 The in vitro propagation of guayusa includes three main stages: shoot bud induction, shoot elongation and rooting

22 (Fig. 1). In the first stage, sterilized stakes with axillary buds were cultured on shoot bud induction medium (Fig.

23 1a). Thirty day-old shoots were then separated from the stake and transferred to fresh medium to allow elongation

24 (Fig. 1b), shoot development (Fig. 1c) and rooting (Fig. 1d).

\section{Plant material}

27 Forty-five, two-year-old, guayusa plants from Runa Foundation nurseries in Tena, Ecuador, were transferred to 28 the Plant Biotechnology Laboratory at Universidad San Francisco de Quito. These plants were used as source 
material for establishing the axillary bud culture protocol. Shoots obtained in vitro were used for elongation,

2 rooting, acclimatization, and light quality assays.

\section{Sterilization protocol}

5 Apical stem segment explants were harvested from two-year-old guayusa plants. The segments were washed in 6 running tap water for 2-4 min. The leaves were dried and removed off, and the stems were cut into $1 \mathrm{~cm}$ stakes with one axillary bud each. The explants were sterilized by submersion in $70 \%$ ethanol for $2 \mathrm{~min}$, followed by

$82,5 \%$ sodium hypochlorite + five drops of Tween ${ }^{\circledR}-20$ for $25 \mathrm{~min}$. Finally, the stakes were washed five times $9 \quad$ with sterile distilled water.

\section{Axillary bud culture}

12 Shoot regeneration from axillary buds was initially tested in two culture media: Murashige \& Skoog with $1 / 4$ of 13 the original salt concentration (1/4 MS) supplemented with 3\% sucrose (pH 5.8); and modified Woody Plant 14 Medium (mWPM) (Lloyd and McCown's, 1981) with 3\% sucrose (pH 5.2) - Table 1. Explants were incubated at $1523 \pm 2^{\circ} \mathrm{C}$ under a $16 \mathrm{~h}$ photoperiod for $47 \mathrm{~d}$. Growth rates were calculated based on shoot size measurements 16 every three days for two months. The final medium used for shoot regeneration was mWPM supplemented with 17 activated charcoal (AC) at $2 \mathrm{~g}^{-1}$.

\section{Elongation and rooting}

20 Shoots obtained from the axillary bud culture $(>0.5 \mathrm{~cm})$ were separated from the stakes and cultivated in mWPM

$21+\mathrm{AC}\left(2 \mathrm{~g} \mathrm{l}^{-1}\right)$. Shoots were grown at $23 \pm 2^{\circ} \mathrm{C}$ in a $16 \mathrm{~h}$ photoperiod. Data were collected every four weeks for 22 six months regarding shoot development, plantlet height, and leaf number and length. Length measurements were 23 performed using a size standard and analyzed in ImageJ (Image processing software).

24 Root development was scored with the analysis of primary and secondary root number and length. Plantlets that 25 rooted spontaneously were transferred to soil for acclimatization. Plantlets that did not develop roots 26 spontaneously were transferred to $\mathrm{mWPM}+4.5 \mu \mathrm{M}, 9.1 \mu \mathrm{M}$ IBA (indole-3-butyric acid) to gather preliminary 27 data on the effect of IBA on rooting induction. Plantlets that developed browning were discarded. 


\section{$1 \quad$ Acclimatization}

2 Plantlets that did not show browning and that developed spontaneous roots were transferred from in vitro 3 conditions to autoclaved soil, and covered with plastic wrap in order to gradually reduce the relative humidity.

4 Plants were then kept in the tissue culture room under a $16 \mathrm{~h}$ photoperiod of white light at $23 \pm 2{ }^{\circ} \mathrm{C}$ for $30 \mathrm{~d}$.

5 Growth and development was assessed over these $30 \mathrm{~d}$ by recording leaf area, shoot length, and root 6 development.

\section{$8 \quad$ Light treatments}

9 Light was provided by LED sources (Light Emitting Computers, Victoria, BC, Canada) with four independent 10 channels: $450 \mathrm{~nm}($ Blue - B), $520 \mathrm{~nm}($ Green - G), $660 \mathrm{~nm}($ Red - R), and $735 \mathrm{~nm}$ (Far-Red - FR). The assays 11 were conducted in enclosed wooden boxes covered with aluminum foil. Light was applied at various fluence 12 rates with a $16 \mathrm{~h}$ photoperiod. Fluence rates within the visible range were measured with a full-spectrum quantum 13 meter (Apogee, model MQ-500) and far-red fluence rates with an International Light meter (model IL1400A). 14 Seven light treatments were tested (Control - T7): Control: cool fluorescent white light $\left(50 \mu \mathrm{mol} \mathrm{m}{ }^{-2} \mathrm{~s}^{-1}\right) ; \mathrm{T} 1: \mathrm{R}$ $15\left(25 \mu \mathrm{mol} \mathrm{m} \mathrm{s}^{-1}\right)+\mathrm{B}\left(25 \mu \mathrm{mol} \mathrm{m}^{-2} \mathrm{~s}^{-1}\right)$; T2: R $\left(25 \mu \mathrm{mol} \mathrm{m}^{-2} \mathrm{~s}^{-1}\right)+\mathrm{B}\left(25 \mu \mathrm{mol} \mathrm{m}^{-2} \mathrm{~s}^{-1}\right)+\mathrm{G}\left(5 \mu \mathrm{mol} \mathrm{m} \mathrm{s}^{-1}\right)$; T3: R $16\left(25 \mu \mathrm{mol} \mathrm{m} \mathrm{s}^{-2}\right)+\mathrm{B}\left(25 \mu \mathrm{mol} \mathrm{m} \mathrm{m}^{-2}\right)+\mathrm{FR} 1\left(4 \mu \mathrm{mol} \mathrm{m} \mathrm{s}^{-1}\right)$; T4: R $\left(25 \mu \mathrm{mol} \mathrm{m}{ }^{-2} \mathrm{~s}^{-1}\right)+\mathrm{B}\left(25 \mu \mathrm{mol} \mathrm{m}^{-2} \mathrm{~s}^{-1}\right)+$ 17 FR2 $\left(16 \mu \mathrm{mol} \mathrm{m} \mathrm{s}^{-1}\right)$; T5: R $\left(25 \mu \mathrm{mol} \mathrm{m} \mathrm{s}^{-1}\right)+\mathrm{B}\left(25 \mu \mathrm{mol} \mathrm{m} \mathrm{s}^{-1}\right)+\mathrm{G}\left(5 \mu \mathrm{mol} \mathrm{m} \mathrm{s}^{-1}\right)+\mathrm{FR} 1\left(4 \mu \mathrm{mol} \mathrm{m} \mathrm{s}^{-1}\right)$;

18 and T6: R $\left(25 \mu \mathrm{mol} \mathrm{m}^{-2} \mathrm{~s}^{-1}\right)+\mathrm{B}\left(25 \mu \mathrm{mol} \mathrm{m} \mathrm{s}^{-1}\right)+\mathrm{G}\left(5 \mu \mathrm{mol} \mathrm{m} \mathrm{s}^{-1}\right)+\mathrm{FR} 2\left(16 \mu \mathrm{mol} \mathrm{m} \mathrm{s}^{-1}\right)-$ Table 2. Eight 19 shoots were grown and evaluated per light treatment, as described above. Data were recorded for each plantlet 20 and average numbers were calculated under each light treatment.

\section{Statistical analyses}

23 Differences between culture media used for axillary bud propagation were evaluated based on a t-test for each 24 variable with an $\alpha$-value of $0.05(n=48)$. In shoot elongation, root development, and plant acclimatization assays 25 data were analyzed using Ordinary one-way ANOVA Multiple comparisons. The six LED treatments were 26 compared to white light. Under the seven light regimens and in vitro conditions results are representative of seven 27 to eight plants per treatment. After transfer to soil results are representative of four to six plants per light 
treatment. Box plots were created in GraphPad Prism. The composite images were configured and labeled in

2 Microsoft PowerPoint.

\section{Results}

\section{Effects of culture media on shoot regeneration from axillary buds}

6 An initial assay was performed to establish an optimal medium for shoot bud induction. Sterilized stakes were 7 cultivated on 1/4 MS and mWPM media during a period of $47 \mathrm{~d}$ (Fig. 1a). Shoot bud induction was evaluated

8 every two or three days by recording shoot length. Although no significant differences were seen between the two 9 tested media (Fig. S1), our visual observations suggested that mWPM resulted in slightly longer shoots than 1/4

10 MS. Based on these observations, and on reports in the literature (Mccown and Sellmer 1987), mWPM was 11 selected as the growth medium for axillary bud regeneration and shoot elongation, and it was supplemented with 12 activated charcoal (AC), Fig. 1.

\section{Shoot elongation and leaf development over four subcultures}

15 Shoot elongation was assessed starting with 30-d-old shoots on mWPM + AC under white light. Four subcultures 16 were performed during $150 \mathrm{~d}$ (Fig. 2). In each subculture, shoots were transferred to fresh growth medium. The 17 material used in the first subculture showed on average a shoot length of $0.6 \mathrm{~cm}$ (Fig. 2a). The second subculture 18 was performed at $90 \mathrm{~d}$, and shoots had almost doubled their length since the first subculture (Fig. 2b). The third 19 subculture was performed $60 \mathrm{~d}$ later, and shoot length showed an increase of 50\%. The fourth and last subculture 20 was performed at $180 \mathrm{~d}$. At this stage, shoot length had reached $2 \mathrm{~cm}$.

21 Leaf emergence initiated after the first subculture (from 60 to $90 \mathrm{~d}$ ). Leaf length was therefore assessed over the 22 three remaining subcultures (Fig. 3). At $90 \mathrm{~d}$, shoots showed a leaf length with $1 \mathrm{~cm}$ on average (Fig. 3a). Leaf 23 length did not change considerably over the remaining two subcultures (Fig. 3b and 3c). At $180 \mathrm{~d}$, leaf length was $24 \quad 1.2 \mathrm{~cm}$ (Fig. 3c).

\section{Root formation}

27 During the fourth and fifth subcultures, $69 \%$ of the plantlets had developed roots spontaneously (Fig. 4). A 28 preliminary assay tested the effect of IBA supplementation on root induction with plantlets that did not root 
1 spontaneously. IBA was tested at two concentrations: $4.5 \mu \mathrm{M}$ and $9.1 \mu \mathrm{M}$. Analysis of root development pointed to $4.5 \mu \mathrm{M}$ IBA as the most effective concentration for rooting induction (Fig. S2).

\section{Acclimatization}

5 Plantlets with roots that developed spontaneously were transferred to soil for acclimatization (Fig. 1d, Fig. 5).

6 Most plants under treatments T3 and T4 did not develop spontaneous roots and were not acclimatized. During the

7 first $30 \mathrm{~d}$ after the beginning of acclimatization, plants that were grown under white light conditions in in vitro

8 conditions roughly maintained a shoot length of $2 \mathrm{~cm}$ (Fig. 6). Leaf area in contrast increased $89 \%$, from 0.39 to

$93.56 \mathrm{~cm}^{2}$ (Fig. 7). Root development was assessed at the beginning of acclimatization in plants that had

10 spontaneously developed roots. Plants grown under white light showed about 14 main roots (Fig. 8a) and five

11 secondary roots (Fig. 8b). Main roots had $0.37 \mathrm{~cm}$ and secondary roots had $0.21 \mathrm{~cm}$ in length (Fig. 9).

\section{Effects of light quality on the in vitro propagation of guayusa}

14 The described protocol for the in vitro propagation of guayusa was tested under different light conditions (Table

15 2). Treatments $\mathrm{T} 1$ and $\mathrm{T} 2$ resulted in a shoot length similar to white light conditions during the four subcultures

16 (Fig. 2), except during the last subculture. At this point shoots grown under T1 showed an average length of 1.44

$17 \mathrm{~cm}, 28 \%$ less than under white light (Fig. 2d). More notable differences were observed when comparing

18 treatments T3 to T6 and white light. During the second subculture shoots grown under T3 to T6 measured from

190.54 to $0.71 \mathrm{~cm}$ (Fig. $2 \mathrm{~b}$ ). These numbers are reduced $45 \%$ to $30 \%$ compared to white light. At $180 \mathrm{~d}$ of growth,

20 during the last subculture, treatments T3 to T6 maintained a similar trend and resulted in shorter shoots, with 1.1

21 to $1.3 \mathrm{~cm}$ in length (a $47 \%$ to $37 \%$ reduction compared to white light-grown shoots). When assessing leaf

22 development during three subcultures, no differences were detected between the white light control and

23 treatments T1 to T6 (Fig. 3 and Fig. S3).

24 The effects of specific light treatments were further assessed within the first $30 \mathrm{~d}$ of acclimatization (Fig. 6-10) in

25 plants that spontaneously developed roots. Treatments T3 and T4 were excluded from this analysis as the

26 majority of plants under these light regimes did not develop roots spontaneously. Both at the beginning of

27 acclimatization and $30 \mathrm{~d}$ later, shoots grown in vitro under T1, T2, T5, and T6 were similar in length to shoots

28 grown under white light (Fig. 6). No differences were seen in leaf area, and LED-grown plants showed similar 
1 trends in leaf growth compared to the white light control (Fig. 7). In terms of root development at the beginning

2 of acclimatization all light conditions except T5 resulted in similar numbers of main and secondary roots per

3 plant (Fig. 8). Under T5 the number of main roots was reduced $65 \%$ when compared to white light - five main

4 roots per plant in $\mathrm{T} 5$ in contrast to 14 main roots in $\mathrm{C}$ (Fig. 8a). Also at the stage of plant transfer to soil,

5 treatments T1, T5, and T6 showed longer main roots than the white light control (Fig. 9a). T1 resulted in main

6 roots with $0.68 \mathrm{~cm}$, T5 in $0.78 \mathrm{~cm}$, and T6 in $0.68 \mathrm{~cm}$, which is $46 \%, 53 \%$ and $46 \%$ longer than white light

7 conditions, respectively. Secondary root length was similar in all light conditions (Fig. 9b).

\section{Discussion}

10 The Amazon rain forest is home to thousands of potentially therapeutic plants and is an important resource to

11 screen for novel drugs (Schultes 1994; Skirycz et al. 2016). A number of these plants have been described but a

12 large fraction remains to be explored and characterized. Traditional medicine in the Amazonian countries largely

13 depends on local plants but native people use outdated cultivation practices that pose a threat to the forest (World

14 Health Organization 2002; Bussmann 2013). At large scale, the systematic usage of plant natural compounds has

15 been limited by factors such as supply problems and low yields (Skirycz et al. 2016). This situation presents a

16 perilous situation, as plants may be subject to un-sustainable harvesting from natural areas, or their natural areas

17 may be compromised to facilitate their growth and propagation. The sustainable usage of Amazonian plants

18 requires the development and implementation of efficient propagation and growth strategies.

19 The in vitro propagation of plants is a sustainable solution to propagate plants that can achieve high yields and

20 year-round predictable products (Opabode 2017; El-Sherif 2019). The current work reports a protocol for the in

21 vitro propagation of the Amazonian medicinal plant guayusa. Guayusa is largely used in Ecuador but its

22 international market is rapidly growing (Wise and Negrin 2020). To facilitate entry of guayusa-based products in

23 restricted markets, safety and risks to human health have been assessed, and adverse effects have not been

24 reported (Wise and Negrin 2020). These observations can reassure regulatory entities and consumers but do not

25 solve key issues in production systems. Current guayusa cultivation practices are still based on low yield

26 techniques. Our protocol may help solve this problem and reducing ecological impacts of growth areas used in

27 the forest. The next major challenge will be to implement the protocol within local producers. This may be 
1 achieved by establishing a communication platform that involves producers, companies that sell guayusa-based

2 products, and academia.

3 In vitro guayusa plants were obtained from axillary buds using stakes as initial material. The sterilization protocol

4 showed to be effective, and after 14 days of culture, $100 \%$ of the stakes were sterile. $90 \%$ of the stakes developed

5 shoots while 10\% developed browning. Explant browning has been described in other woody plants and shrubs,

6 including some Ilex species (Mroginski et al. 1999). The production of brown substances is predominantly caused

7 by enzymatic oxidation of phenolic compounds, and often causes explant death. The toxic substances and the

8 obstruction of oxidized tissues restrain nutrient absorption from the growth medium (Tarragó et al. 2012).

9 Previous studies were able to reduce oxidation with AC supplementation, a carbonaceous adsorbent of aromatic

10 compounds (de Cássia Tomasi et al. 2019). Similar results were observed in this study, and $2 \mathrm{~g} \mathrm{l}^{-1}$ of AC in the

11 growing media significantly reduced oxidation up to $90 \%$.

12 Two culture media compositions were tested for shoot regeneration and elongation. WPM was first developed for

13 shoot culture of woody plants and bushes and for tree propagation, and is currently the second most used medium

14 for in vitro culture (Jain and Häggman 2007). WPM is characterized by having low salt concentrations, since

15 many woody species are known to be sensitive to $\mathrm{NaCl}$. WPM minimizes chloride levels by using sulfate salts

16 (Mccown and Sellmer 1987). Moreover, WPM has low levels of ammonium nitrate, which prevents shoot

17 vitrification (Huang and Dai 2011) and decreases the percentage of nodal browning in woody species (Mroginski

18 et al. 1999). The MS medium provides similar nutritional values as WPM but presents high $\mathrm{NH}_{4} \mathrm{NO}_{3}$ and $\mathrm{KNO}_{3}$

19 levels. A reduced basal concentration of this medium (1/4 MS) benefits shoot regeneration and decreases

20 browning (Mroginski et al. 1999). In shoot regeneration of Quercus ilex L. (holm oak), a recalcitrant woody

21 species of difficult propagation, MS medium yielded small leaves, while WPM resulted in larger shoots

22 (Martínez et al. 2017). These observations are consistent with our observations where, despite the absence of

23 significant differences, plant vigor was more evident on mWPM.

24 Plantlets that presented three to five extended leaves and spontaneously developed roots were successfully

25 acclimatized in soil. Plants that did not root spontaneously often showed one of two main characteristics: shoot

26 tip necrosis (STN) or less developed shoots. STN is a physiological condition that can emerge in in vitro plantlets

27 or shoots and affect propagation by causing tissue death (Bairu et al. 2009). STN has been reported in several

28 arboreal and shrubby plants (Teixeira da Silva et al. 2020). Furthermore, the usage of short shoots (less than 0.5 
$1 \mathrm{~cm}$ in length) affects the elongation phase and delays roots appearance, which can lead to nutrient deficiency in

2 the plant (Martínez et al. 2017).

3 Plantlets that do not root spontaneously and do not show STN or less developed shoots may be transferred to 4 rooting induction conditions. Phytohormones are routinely needed in such approaches. Specific compounds and 5 their concentrations largely vary within woody species and depend on the type of cutting (Haissig 1986). Still, it

6 has been suggested that rooting in woody plants is responsive to IBA, and to a lesser extent to NAA (17 naphthaleneacetic acid) (Azad et al. 2005). IBA is the most commonly auxin used for root formation in woody 8 species due to its higher stability (Rathore et al. 2005). For instance, vegetative propagation of Ilex khasiana, as 9 in other woody plants, is slow and root formation is the most challenging step (Dang et al. 2011). An effective 10 treatment for root formation is $9.84 \mu \mathrm{M}$ IBA, resulting in $93.33 \%$ of developed roots in 4-week-old shoots (Dang 11 et al. 2011). Similar findings have been observed in other shrubs and woody species, such as Ilex aquifolium 12 (Dennis Thomas and Yoichiro 2010). In our preliminary assay that analyzed the impact of IBA on rooting 13 induction we tested a similar amount of IBA $(9.1 \mu \mathrm{M})$ and roughly half of it $(4.5 \mu \mathrm{M})$. We obtained better results 14 with $4.5 \mu \mathrm{M}$ IBA, getting overall higher number of roots per shoots (Fig. S2). Further work with additional 15 samples is needed.

16 The protocol for the in vitro propagation of guayusa can be modulated with selective light conditions, instead of 17 using a traditional white light source. Light modulates plant growth and development and knowledge often 18 obtained from the model Arabidopsis has facilitated crop manipulation and improvement with light environments 19 (Paik and Huq 2019; Landi et al. 2020). Translation of such approaches to underexplored crops such as guayusa 20 is limited by the poor knowledge of how this species responds to light. Guayusa grows in dense vegetation and is 21 tolerant to shade, in contrast to Arabidopsis. It is expectable that guayusa and Arabidopsis may differ in their 22 responses to similar light conditions.

23 Leaf number per shoot was recorded from subcultures two to four in plants grown under the seven light 24 conditions (Fig. S3). Handling of the plant material during each subculture leads however to a few leaves falling 25 off from the shoots, making it impossible to accurately quantify leaf emergence and to assess effects of light 26 quality on plant development based on leaf number.

27 The major impact of light depicted in this experimental approach was in root development. Most shoots grown 28 under T3 and T4 treatments did not develop roots spontaneously and were therefore transferred to growth 
1 medium supplemented with IBA to induce rooting. These plants were excluded from the analysis of acclimatized

2 plants (Fig. 6 to 9). Both T3 and T4 have FR light added to a background of R and B at two different red:far-red

3 (R:FR) ratios (T3: 6.3 and T4: 1.6). Supplemental far-red light at the referred R:FR ratios may therefore inhibit

4 root development of guayusa. At the initiation of acclimatization, treatments T1, T5, and T6 resulted in longer

5 main roots than the control and other LED conditions. In addition, T5 reduced the number of main roots and

6 caused longer secondary roots compared to the other regimens. T5 and T6 have G light added to R/B (T1) and FR

7 light at the R:FR ratios 6.3 and 1.6, respectively. Since no major differences were observed in T2 (G light added

8 to R/B), and given the delayed root development under T3 and T4, it may be possible that the results observed in

9 T5 result from a synergistic effect of G and FR light on root development. Both G and FR light have been

10 implicated in the modulation of root development and morphology, although the role of the latter has been more

11 explored and established at molecular levels (Webb 1981; Gelderen et al. 2018b; Klem et al. 2019; Xu et al.

12 2020; Mølmann et al. 2020). In Arabidopsis, a shoot-to-root communication system senses supplemental FR

13 enrichment (ratio R:FR 0.1) and reduces lateral root emergence and density through the modulation of the

14 transcription factor ELONGATED HYPOCOTYL 5 (HY5) activity, which regulates auxin signaling (Gelderen et

15 al. 2018a). This regulation of root growth by reduced ratios of R:FR occurs in dense vegetation, where shade-

16 avoidance responses are activated in shade intolerant plants such as Arabidopsis (Morelli and Ruberti 2000;

17 Pierik and de Wit 2014). Green light is also an important environmental cue in shade avoidance (Zhang et al.

18 2011). Green and FR light control shade avoidance in Arabidopsis through the activity of several photoreceptors,

19 including phytochrome, cryptochrome and an unknown green sensor (Sellaro et al. 2010; Zhang et al. 2011;

20 Gelderen et al. 2018b). The activity of such light sensors may be explored in guayusa in future studies in order to

21 gain insight on the mechanisms that have evolved in this Amazonian plant.

22 The current study used $50 \mu \mathrm{mol} \mathrm{m} \mathrm{s}^{-1}$ as the background fluence rate because it is the fluence rate provided by

23 the white light sources currently installed in our plant tissue room. Our current LED system limited the creation

24 of additional light environments with different wavelength ratios. In the future we aim at testing higher fluence

25 rates with various wavelengths on guayusa propagation. It will be particularly relevant to analyze the impact of

26 reduced R:FR ratios $(<0.7)$ together with G light enrichment and B light depletion to simulate dense vegetation

27 conditions (Morelli and Ruberti 2000; Gelderen et al. 2018b). 
1 Guayusa leaves accumulate several compounds of interest, including phenolic compounds, terpenoids, and the

2 methylxanthines caffeine and theobromine (Wise and Negrin 2020). Light quality and quantity will be tested on

3 leaf characteristics in the future with the aim of enhancing guayusa properties. Leaf metabolites have been

4 manipulated with light in aromatic and medicinal species such as basil, parsley, tea, and water mint (Fu et al.

5 2015; Carvalho et al. 2016; Ascrizzi et al. 2018; Pennisi et al. 2019; Zheng et al. 2019; Wang et al. 2020; Nazari

6 and Zarinkamar 2020). Identifying proper light conditions to stimulate leaf quality will facilitate obtaining

7 reliable products unaffected by environmental fluctuations. Fluctuations of light cues occur in forests and affect

8 leaf metabolite synthesis (Zhang et al. 2018a, b). It is interesting to note that treatments T2, T4 and T6 resulted in

9 lower variances in each trait studied, suggesting these light conditions may be used to obtain consistent guayusa

10 plants.

11

\section{Conclusions}

13 Guayusa was propagated from axillary buds on mWPM supplemented with AC. After 180 days plants that 14 developed roots spontaneously were ready for acclimatization in soil. In shoots with delayed or absent rooting,

15 root initiation may be stimulated with supplementation of $4.5 \mu \mathrm{m}$ IBA. Light quality was tested on plant 16 propagation, and an effect of green and far-red light was observed on root growth. Future studies will further 17 explore the impact of light of guayusa development, with an emphasis on leaf quality and the onset of flowering.

18 This study can sustain similar projects in other potential medicinal plants and facilitate drug discovery with 19 sustainable approaches.

\section{Declarations}

\section{Funding}

23 This work was supported by Fundación Runa and by Universidad San Francisco de Quito USFQ, Colegio de 24 Ciencias Biológicas y Ambientales COCIBA Grants - Hubi 12431.

\section{Conflicts of interest}

27 The authors have no conflicts of interest to declare. 
2 The datasets generated during and/or analyzed during the current study are available from the corresponding 3 author on reasonable request.

\section{Code availability}

$6 \quad$ Not applicable.

\section{Authors' contributions}

9 MLT supervised the project. MLT, SC conceptualized the project. SC, MaO, and MLT designed the experiments, 10 examined results. $\mathrm{MaO}, \mathrm{MiO}$, and $\mathrm{MR}$ performed the experiments, compiled and analyzed the data. KF made

11 available the light sources and provided insight in result interpretations. SC and $\mathrm{MaO}$ prepared and wrote the 12 manuscript. MLT provided feedback and editions during manuscript preparation. SC and MLT obtained funding

13 for the study, oversaw experiments. All authors approved the manuscript.

\section{Acknowledgments}

16 The LED sources were installed in the plant tissue culture room with the dedicated contribution from the 17 Physical Plant Team of USFQ. We thank Runa Foundation for sharing the guayusa plants used as source 18 material, the Laboratory of Plant Biotechnology at USFQ for daily and continuous support during the 19 development of this project, and Wa and David Garcia for sharing information on methods used for guayusa 20 growth and details on production systems. We thank Venancio Arahana, Andrea Montero and María Mercedes 21 Cobo for assisting in experimental design of preliminary propagation trials. We thank Raquel Carvalho for 22 helpful discussion and reviewing of the manuscript.

\section{References}

Ascrizzi R, Fraternale D, Flamini G (2018) Photochemical response of parsley (Petroselinum crispum (Mill.) Fuss) grown under red light: The effect on the essential oil composition and yield. Journal of Photochemistry and Photobiology B: Biology 185:185-191. https://doi.org/10.1016/j.jphotobiol.2018.06.006 
Azad MAK, Yokota S, Ohkubo T, et al (2005) In vitro regeneration of the medicinal woody plant Phellodendron amurense Rupr. through excised leaves. Plant Cell Tiss Organ Cult 80:43-50. https://doi.org/10.1007/s11240-004-8809-5

Bairu MW, Stirk WA, Van Staden J (2009) Factors contributing to in vitro shoot-tip necrosis and their physiological interactions. Plant Cell Tiss Organ Cult 98:239-248. https://doi.org/10.1007/s11240-0099560-8

Ballaré CL, Pierik R (2017) The shade-avoidance syndrome: multiple signals and ecological consequences. Plant, Cell \& Environment 40:2530-2543. https://doi.org/10.1111/pce.12914

Bussmann RW (2013) The Globalization of Traditional Medicine in Northern Peru: From Shamanism to Molecules. Evid Based Complement Alternat Med 2013:. https://doi.org/10.1155/2013/291903

Carvalho SD, Folta KM (2014) Environmentally modified organisms-expanding genetic potential with light. Critical reviews in plant sciences 33:486-508

Carvalho SD, Schwieterman ML, Abrahan CE, et al (2016) Light Quality Dependent Changes in Morphology, Antioxidant Capacity, and Volatile Production in Sweet Basil (Ocimum basilicum). Front Plant Sci $7: 1328$

Chianese G, Golin-Pacheco SD, Taglialatela-Scafati O, et al (2019) Bioactive triterpenoids from the caffeine-rich plants guayusa and maté. Food Res Int 115:504-510. https://doi.org/10.1016/j.foodres.2018.10.005

Dang JC, Kumaria S, Kumar S, Tandon P (2011) Micropropagation of Ilex khasiana, a critically endangered and endemic holly of Northeast India. AoB PLANTS 2011:. https://doi.org/10.1093/aobpla/plr012

Darko E, Heydarizadeh P, Schoefs B, Sabzalian MR (2014) Photosynthesis under artificial light: the shift in primary and secondary metabolism. Philos Trans R Soc Lond, B, Biol Sci 369:20130243. https://doi.org/10.1098/rstb.2013.0243

de Cássia Tomasi J, Degenhardt-Goldbach J, Lucia Grunennvaldt R, et al (2019) In vitro establishment of shoot meristems of Ilex paraguariensis and identification of endophytic bacteria. J For Res 30:1765-1777. https://doi.org/10.1007/s11676-018-0763-x

Dennis Thomas T, Yoichiro H (2010) In vitro propagation for the conservation of a rare medicinal plant Justicia gendarussa Burm. f. by nodal explants and shoot regeneration from callus. Acta Physiol Plant 32:943950. https://doi.org/10.1007/s11738-010-0482-1

Dolce NR, Mroginski LA, Rey HY (2011) Enhanced Seed Germination of Ilex dumosa R. (Aquifoliaceae) through In Vitro Culture of Cut Pyrenes. HortScience 46:278-281. https://doi.org/10.21273/HORTSCI.46.2.278

Dueñas JF, Jarrett C, Cummins I, Logan-Hines E (2016) Amazonian Guayusa (Ilex guayusa Loes.): A Historical and Ethnobotanical Overview. Econ Bot 70:85-91. https://doi.org/10.1007/s12231-016-9334-2

El Comercio (2018) Napo exporta 120 toneladas de la hoja sagrada de guayusa a tres países. https://www.elcomercio.com/actualidad/napo-exportacion-guayusa-ecuador-bebida.html. Accessed 14 Jul 2020

El-Sherif NA (2019) Impact of Plant Tissue Culture on Agricultural Sustainability. In: Negm AM, Abu-hashim M (eds) Sustainability of Agricultural Environment in Egypt: Part II: Soil-Water-Plant Nexus. Springer International Publishing, Cham, pp 93-107 
Fankhauser C, Christie JM (2015) Plant phototropic growth. Curr Biol 25:R384-389. https://doi.org/10.1016/j.cub.2015.03.020

3 FAO (2008) Erosion of plant genetic diversity.

4 http://www.fao.org/newsroom/en/focus/2004/51102/article_51107en.html. Accessed 14 Jul 2020

5 Fu X, Chen Y, Mei X, et al (2015) Regulation of formation of volatile compounds of tea (Camellia sinensis) leaves by single light wavelength. Scientific Reports 16 :

Fundación Futuro Latinoamericano and Grupo FARO (2020) ODS Territorio Ecuador. https://odsterritorioecuador.ec/. Accessed 14 Jul 2020

9 Galvão VC, Fankhauser C (2015) Sensing the light environment in plants: photoreceptors and early signaling steps. Current Opinion in Neurobiology 34:46-53. https://doi.org/10.1016/j.conb.2015.01.013

Gamboa F, Muñoz C-C, Numpaque G, et al (2018) Antimicrobial Activity of Piper marginatum Jacq and Ilex guayusa Loes on Microorganisms Associated with Periodontal Disease. Int J Microbiol 2018:4147383. https://doi.org/10.1155/2018/4147383

Gan R-Y, Zhang D, Wang M, Corke H (2018) Health Benefits of Bioactive Compounds from the Genus Ilex, a Source of Traditional Caffeinated Beverages. Nutrients 10:. https://doi.org/10.3390/nu10111682

García-Ruiz A, Baenas N, Benítez-González AM, et al (2017) Guayusa (Ilex guayusa L.) new tea: phenolic and carotenoid composition and antioxidant capacity. J Sci Food Agric 97:3929-3936. https://doi.org/10.1002/jsfa. 8255

Gelderen K van, Kang C, Paalman R, et al (2018a) Far-Red Light Detection in the Shoot Regulates Lateral Root Development through the HY5 Transcription Factor. The Plant Cell 30:101-116. https://doi.org/10.1105/tpc.17.00771

Gelderen K van, Kang C, Pierik R (2018b) Light Signaling, Root Development, and Plasticity. Plant Physiology 176:1049-1060. https://doi.org/10.1104/pp.17.01079

Giovannini P (2015) Medicinal plants of the Achuar (Jivaro) of Amazonian Ecuador: ethnobotanical survey and comparison with other Amazonian pharmacopoeias. J Ethnopharmacol 164:78-88. https://doi.org/10.1016/j.jep.2015.01.038

Gu R, Wang Y, Long B, et al (2014) Prospecting for bioactive constituents from traditional medicinal plants through ethnobotanical approaches. Biol Pharm Bull 37:903-915. https://doi.org/10.1248/bpb.b1400084

Haissig BE (1986) Metabolic processes in adventitious rooting of cuttings. In: Jackson MB (ed) New Root Formation in Plants and Cuttings. Springer Netherlands, Dordrecht, pp 141-189

Huang D, Dai W (2011) Direct regeneration from in vitro leaf and petiole tissues of Populus tremula 'Erecta.' Plant Cell Tiss Organ Cult 107:169-174. https://doi.org/10.1007/s11240-011-9955-1

34 Innerhofer S, Bernhardt K-G (2011) Ethnobotanic garden design in the Ecuadorian Amazon. Biodivers Conserv 35 20:429-439. https://doi.org/10.1007/s10531-010-9984-9

36 Isbell F, Adler PR, Eisenhauer N, et al (2017) Benefits of increasing plant diversity in sustainable

37 agroecosystems. Journal of Ecology 105:871-879. https://doi.org/10.1111/1365-2745.12789 
Jain SM, Häggman H (eds) (2007) Protocols for Micropropagation of Woody Trees and Fruits. Springer Netherlands

Kapp RW, Mendes O, Roy S, et al (2016) General and Genetic Toxicology of Guayusa Concentrate (Ilex guayusa). Int J Toxicol 35:222-242. https://doi.org/10.1177/1091581815625594

Klem K, Gargallo-Garriga A, Rattanapichai W, et al (2019) Distinct Morphological, Physiological, and Biochemical Responses to Light Quality in Barley Leaves and Roots. Front Plant Sci 10:1026. https://doi.org/10.3389/fpls.2019.01026

Krause T, Ness B (2017) Energizing agroforestry: Ilex guayusa as an additional commodity to diversify Amazonian agroforestry systems. International Journal of Biodiversity Science, Ecosystem Services \& Management 13:191-203. https://doi.org/10.1080/21513732.2017.1303646

Landi M, Zivcak M, Sytar O, et al (2020) Plasticity of photosynthetic processes and the accumulation of secondary metabolites in plants in response to monochromatic light environments: A review. Biochim Biophys Acta Bioenerg 1861:148131. https://doi.org/10.1016/j.bbabio.2019.148131

Legris M, Ince YÇ, Fankhauser C (2019) Molecular mechanisms underlying phytochrome-controlled morphogenesis in plants. Nat Commun 10:5219. https://doi.org/10.1038/s41467-019-13045-0

Leone A, Grillo S, Monti L, Cardi T (2007) Molecular tailoring and boosting of bioactive secondary metabolites in medicinal plants. In: RANALLI P (ed) Improvement of Crop Plants for Industrial End Uses. Springer Netherlands, Dordrecht, pp 471-507

Martínez MT, Corredoira E, Vieitez AM, et al (2017) Micropropagation of mature Quercus ilex L. trees by axillary budding. Plant Cell Tiss Organ Cult 131:499-512. https://doi.org/10.1007/s11240-017-1300-x

Mccown BH, Sellmer JC (1987) General Media and Vessels Suitable for Woody Plant Culture. In: Bonga JM, Durzan DJ (eds) Cell and Tissue Culture in Forestry: General Principles and Biotechnology. Springer Netherlands, Dordrecht, pp 4-16

Mølmann JA, Hansen E, Johansen TJ (2020) Effects of supplemental LED light quality and reduced growth temperature on swede (Brassica napus L. ssp. rapifera Metzg.) root vegetable development and contents of glucosinolates and sugars. J Sci Food Agric. https://doi.org/10.1002/jsfa.10866

Morelli G, Ruberti I (2000) Shade Avoidance Responses. Driving Auxin along Lateral Routes. Plant Physiology 122:621-626. https://doi.org/10.1104/pp.122.3.621

Mroginski LA, Rouvier SM, Fabisik JC, et al (1999) Effect of medium composition and light supply on in vitro shoot proliferation in Ilex paraguariensis (Aquifoloaceae). Journal of Plant Nutrition 22:359-368. https://doi.org/10.1080/01904169909365633

Nazari M, Zarinkamar F (2020) Ultraviolet-B induced changes in Mentha aquatica (a medicinal plant) at early and late vegetative growth stages: Investigations at molecular and genetic levels. Industrial Crops and Products 154:112618. https://doi.org/10.1016/j.indcrop.2020.112618

Opabode JT (2017) Sustainable Mass Production, Improvement, and Conservation of African Indigenous Vegetables: The Role of Plant Tissue Culture, a Review. International Journal of Vegetable Science 23:438-455. https://doi.org/10.1080/19315260.2017.1319006

Paik I, Huq E (2019) Plant photoreceptors: Multi-functional sensory proteins and their signaling networks. Semin Cell Dev Biol 92:114-121. https://doi.org/10.1016/j.semcdb.2019.03.007 
Pardau MD, Pereira ASP, Apostolides Z, et al (2017) Antioxidant and anti-inflammatory properties of Ilex guayusa tea preparations: a comparison to Camellia sinensis teas. Food Funct 8:4601-4610. https://doi.org/10.1039/c7fo01067b

Pennisi G, Blasioli S, Cellini A, et al (2019) Unraveling the Role of Red:Blue LED Lights on Resource Use Efficiency and Nutritional Properties of Indoor Grown Sweet Basil. Front Plant Sci 10: https://doi.org/10.3389/fpls.2019.00305

Perreault T (2005) Why Chacras (Swidden gardens) Persist: Agrobiodiversity, Food Security, and Cultural identity in the Ecuadorian Amazon. Human Organization 64:327-339. https://doi.org/10.17730/humo.64.4.e6tymmka388rmybt

Pierik R, de Wit M (2014) Shade avoidance: phytochrome signalling and other aboveground neighbour detection cues. J Exp Bot 65:2815-2824. https://doi.org/10.1093/jxb/ert389

Radice, M., Cossio, N., Scalvenzi, L. (2017) Ilex guayusa : A systematic review of its Traditional Uses , Chemical Constituents, Biological Activities and Biotrade Opportunities. Mol2Net

Rathore JS, Rathore V, Shekhawat NS, et al (2005) Micropropagation of Woody Plants. In: Srivastava PS, Narula A, Srivastava S (eds) Plant Biotechnology and Molecular Markers. Springer Netherlands, Dordrecht, pp 195-205

Robles Arias DM, Cevallos D, Gaoue OG, et al (2020) Non-random medicinal plants selection in the Kichwa community of the Ecuadorian Amazon. J Ethnopharmacol 246:112220. https://doi.org/10.1016/j.jep.2019.112220

Schuchovski CS, Biasi LA (2019) In Vitro Establishment of 'Delite' Rabbiteye Blueberry Microshoots. Horticulturae 5:24. https://doi.org/10.3390/horticulturae5010024

Schultes RE (1994) Amazonian ethnobotany and the search for new drugs. Ciba Found Symp 185:106-112; discussion 112-115

Sellaro R, Crepy M, Trupkin SA, et al (2010) Cryptochrome as a sensor of the blue/green ratio of natural radiation in Arabidopsis. Plant Physiol 154:401-409. https://doi.org/10.1104/pp.110.160820

Skirycz A, Kierszniowska S, Méret M, et al (2016) Medicinal Bioprospecting of the Amazon Rainforest: A Modern Eldorado? Trends Biotechnol 34:781-790. https://doi.org/10.1016/j.tibtech.2016.03.006

Tarragó J, Filip R, Mroginski L, Sansberro P (2012) Influence of the irradiance on phenols content and rooting of Ilex paraguariensis cuttings collected from adult plants. Acta Physiol Plant 34:2419-2424. https://doi.org/10.1007/s11738-012-1009-8

Teixeira da Silva JA, Nezami-Alanagh E, Barreal ME, et al (2020) Shoot tip necrosis of in vitro plant cultures: a reappraisal of possible causes and solutions. Planta 252:47. https://doi.org/10.1007/s00425-020-03449-4

Thomas E, Semo L, Morales M, et al (2011) Ethnomedicinal practices and medicinal plant knowledge of the Yuracarés and Trinitarios from Indigenous Territory and National Park Isiboro-Sécure, Bolivian Amazon. Journal of Ethnopharmacology 133:153-163. https://doi.org/10.1016/j.jep.2010.09.017

Trigiano RN, Gray DJ (1999) Plant Tissue Culture Concepts and Laboratory Exercises, Second Edition. CRC Press

Tripathi S, Hoang QTN, Han Y-J, Kim J-I (2019) Regulation of Photomorphogenic Development by Plant Phytochromes. Int J Mol Sci 20:. https://doi.org/10.3390/ijms20246165 
2

Wang P, Chen S, Gu M, et al (2020) Exploration of the Effects of Different Blue LED Light Intensities on Flavonoid and Lipid Metabolism in Tea Plants via Transcriptomics and Metabolomics. Int J Mol Sci 21:. https://doi.org/10.3390/ijms21134606

Wang W, Chen Q, Botella JR, Guo S (2019) Beyond Light: Insights Into the Role of Constitutively Photomorphogenic1 in Plant Hormonal Signaling. Front Plant Sci 10:557. https://doi.org/10.3389/fpls.2019.00557

Webb D (1981) Effects of Light Quality on Root Elongation and Nodulation of Zamia floridana DC. Seedlings in Sterile Culture. Zeitschrift für Pflanzenphysiologie 104:253-258. https://doi.org/10.1016/S0044$328 \mathrm{X}(81) 80119-5$

Wiñak Association (2020) Small Kichwa Farmers working together for the progress of their families and communities. https://www.winak.org/. Accessed 14 Jul 2020

Wise G, Negrin A (2020) A critical review of the composition and history of safe use of guayusa: a stimulant and antioxidant novel food. Crit Rev Food Sci Nutr 60:2393-2404. https://doi.org/10.1080/10408398.2019.1643286

World Health Organization (2002) WHO Traditional Medicine Strategy 2002-2005

Wu S-H (2014) Gene Expression Regulation in Photomorphogenesis from the Perspective of the Central Dogma. Annual Review of Plant Biology 65:311-333. https://doi.org/10.1146/annurev-arplant-050213-040337

Xu Y, Yang M, Cheng F, et al (2020) Effects of LED photoperiods and light qualities on in vitro growth and chlorophyll fluorescence of Cunninghamia lanceolata. BMC Plant Biol 20:269. https://doi.org/10.1186/s12870-020-02480-7

Yadav A, Singh D, Lingwan M, et al (2020) Light signaling and UV-B-mediated plant growth regulation. J Integr Plant Biol. https://doi.org/10.1111/jipb.12932

Yokoya NS, Yoneshigue-Valentin Y (2011) Micropropagation as a tool for sustainable utilization and conservation of populations of Rhodophyta. Revista Brasileira de Farmacognosia 21:334-339. https://doi.org/10.1590/S0102-695X2011005000077

Zhang T, Maruhnich SA, Folta KM (2011) Green light induces shade avoidance symptoms. Plant Physiol 157:1528-1536. https://doi.org/10.1104/pp.111.180661

Zhang T-J, Zheng J, Yu Z-C, et al (2018a) Functional characteristics of phenolic compounds accumulated in young leaves of two subtropical forest tree species of different successional stages. Tree Physiol 38:1486-1501. https://doi.org/10.1093/treephys/tpy030

Zhang T-J, Zheng J, Yu Z-C, et al (2018b) Variations in photoprotective potential along gradients of leaf development and plant succession in subtropical forests under contrasting irradiances. Environmental and Experimental Botany 154:23-32. https://doi.org/10.1016/j.envexpbot.2017.07.016

Zheng C, Ma J-Q, Ma C-L, et al (2019) Regulation of Growth and Flavonoid Formation of Tea Plants (Camellia sinensis) by Blue and Green Light. J Agric Food Chem 67:2408-2419. https://doi.org/10.1021/acs.jafc.8b07050 
3 Table 1. Components of the modified Woody Plant Medium used in this study and Lloyd and McCown's original Woody

$4 \quad$ Plant medium (Trigiano and Gray 1999; Schuchovski and Biasi 2019).

\begin{tabular}{ccc}
\hline Components & Modified WPM $\left(\mathbf{g ~ I}^{-1}\right)$ & Original WPM $\left.\mathbf{~ g ~}^{-1}\right)$ \\
\hline & Macronutrients & \\
& & \\
$\mathrm{NH}_{4} \mathrm{NO}_{3}$ & 5.4 & 0.4 \\
$\mathrm{KNO}_{3}$ & 3.9 & - \\
$\mathrm{CaCl}_{2} \cdot 2 \mathrm{H}_{2} 0$ & 2.8 & 0.096 \\
$\mathrm{MgSO}_{4} \cdot 7 \mathrm{H}_{2} \mathrm{O}$ & 3.7 & 0.37 \\
$\mathrm{KH}_{2} \mathrm{PO}_{4}$ & 1.7 & 0.17 \\
$\mathrm{~K}_{2} \mathrm{SO}_{4}$ & - & 0.99 \\
$\mathrm{Ca}\left(\mathrm{NO}_{3}\right)_{2} \cdot 4 \mathrm{H}_{2} \mathrm{O}$ & - & 0.556 \\
& Micronutrients & \\
& 0.62 & \\
$\mathrm{H}_{3} \mathrm{BO}_{3}$ & 1.69 & 0.0062 \\
$\mathrm{MnSO}_{4} \cdot \mathrm{H}_{2} \mathrm{O}$ & 1.05 & 0.0223 \\
$\mathrm{ZnSO}_{4} \cdot 7 \mathrm{H}_{2} \mathrm{O}$ & 0.083 & 0.0086 \\
$\mathrm{KI}$ & 0.025 & - \\
$\mathrm{Na}_{2} \mathrm{MoO}_{4} \cdot 2 \mathrm{H}_{2} \mathrm{O}$ & 0.0025 & 0.025 \\
$\mathrm{CoCl}_{2} \cdot 6 \mathrm{H}_{2} 0$ & 0.0025 & - \\
$\mathrm{CuSO}_{4} \cdot 5 \mathrm{H}_{2} \mathrm{O}$ & 2.78 & 0.025 \\
$\mathrm{FeSO}_{4} \cdot 7 \mathrm{H}_{2} 0$ & 3.73 & 0.0278 \\
$\mathrm{Na}_{2}-\mathrm{EDTA}$ & & 0.0373 \\
\hline
\end{tabular}


Table 2. Light spectrum and photon flux density in seven treatments.

2

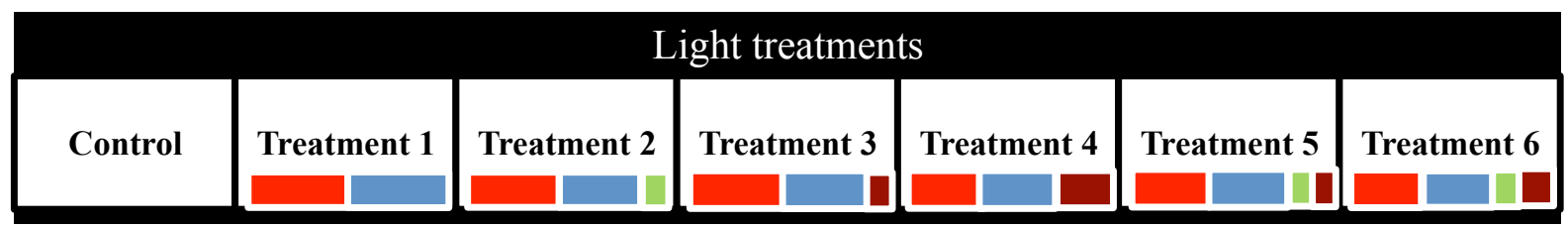

\begin{tabular}{|c|c|c|c|c|c|c|}
\hline $\begin{array}{c}\text { White } \\
\left(50 \mu \mathrm{mol} \mathrm{m}^{-2} \mathrm{~s}^{-1}\right)\end{array}$ & $\begin{array}{c}\text { Red } \\
\left(25 \mu \mathrm{mol} \mathrm{m}^{-2} \mathrm{~s}^{-1}\right)\end{array}$ & $\begin{array}{c}\text { Red } \\
\left(25 \mu \mathrm{mol} \mathrm{m}^{-2} \mathrm{~s}^{-1}\right)\end{array}$ & $\begin{array}{c}\text { Red } \\
\left(25 \mu \mathrm{mol} \mathrm{m}^{-2} \mathrm{~s}^{-1}\right)\end{array}$ & $\begin{array}{c}\text { Red } \\
\left(25 \mu \mathrm{mol} \mathrm{m}^{-2} \mathrm{~s}^{-1}\right)\end{array}$ & $\begin{array}{c}\text { Red } \\
\left(25 \mu \mathrm{mol} \mathrm{m}^{-2} \mathrm{~s}^{-1}\right)\end{array}$ & $\begin{array}{c}\text { Red } \\
\left(25 \mu \mathrm{mol} \mathrm{m}^{-2} \mathrm{~s}^{-1}\right)\end{array}$ \\
\hline & $\begin{array}{c}\text { Blue } \\
\left(25 \mu \mathrm{mol} \mathrm{m}^{-2} \mathrm{~s}^{-1}\right)\end{array}$ & $\begin{array}{c}\text { Blue } \\
\left(25 \mu \mathrm{mol} \mathrm{m}^{-2} \mathrm{~s}^{-1}\right)\end{array}$ & $\begin{array}{c}\text { Blue } \\
\left(25 \mu \mathrm{mol} \mathrm{m}^{-2} \mathrm{~s}^{-1}\right)\end{array}$ & $\begin{array}{c}\text { Blue } \\
\left(25 \mu \mathrm{mol} \mathrm{m}^{-2} \mathrm{~s}^{-1}\right)\end{array}$ & $\begin{array}{c}\text { Blue } \\
\left(25 \mu \mathrm{mol} \mathrm{m}^{-2} \mathrm{~s}^{-1}\right)\end{array}$ & $\begin{array}{c}\text { Blue } \\
\left(25 \mu \mathrm{mol} \mathrm{m}^{-2} \mathrm{~s}^{-1}\right)\end{array}$ \\
\hline & & $\begin{array}{c}\text { Green } \\
\left(5 \mu \mathrm{mol} \mathrm{m}^{-2} \mathrm{~s}^{-1}\right)\end{array}$ & 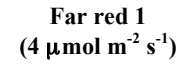 & $\begin{array}{c}\text { Far red 2 } \\
\left(16 \mu \mathrm{mol} \mathrm{m}^{-2} \mathrm{~s}^{-1}\right)\end{array}$ & $\begin{array}{c}\text { Green } \\
\left(5 \mu \mathrm{mol} \mathrm{m}^{-2} \mathrm{~s}^{-1}\right)\end{array}$ & $\begin{array}{c}\text { Green } \\
\left(5 \mu \mathrm{mol} \mathrm{m}^{-2} \mathrm{~s}^{-1}\right)\end{array}$ \\
\hline & & & & & $\begin{array}{c}\text { Far red 1 } \\
\left(4 \mu \mathrm{mol} \mathrm{m}^{-2} \mathrm{~s}^{-1}\right)\end{array}$ & $\begin{array}{c}\text { Far red 2 } \\
\left(16 \mu \mathrm{mol} \mathrm{m}^{-2} \mathrm{~s}^{-1}\right)\end{array}$ \\
\hline
\end{tabular}

4 
3 Fig. 1 In vitro propagation of guayusa from axillary buds using stakes as initial material. Cuttings grown in

4 mWPM + AC medium and exposed to light treatment T2 are shown as representative examples. (a) Developing

5 bud on a stake. (b) 30 d-old shoots ready to be separated from the stake. (c) Shoots after 150 d. (d) Developed

6 roots in $180 \mathrm{~d}$-old shoots

8 Fig. 2 Shoot length in four subcultures. Box plots represent the control and six light conditions, T1 to T6. Results 9 are representative of seven to eight plants per condition. (a) First subculture, $30 \mathrm{~d}$. (b) Second subculture, $90 \mathrm{~d}$.

10 (c) Third subculture, 150 d. (d) Fourth subculture, 180 d. Letters denote significantly different values (one-way 11 ANOVA, $p<0.05)$

13 Fig. 3 Leaf length in three subcultures. Box plots represent the control and six light conditions, T1 to T6. Results 14 are representative of seven to eight plants per treatment. (a) Second subculture, $90 \mathrm{~d}$. (b) Third subculture, $150 \mathrm{~d}$. 15 (c) Fourth subculture, $180 \mathrm{~d}$. Letters denote significantly different values (one-way ANOVA, $p<0.05$ )

Fig. 4 Spontaneous root development after $180 \mathrm{~d}$. Five plantlets grown under light treatment T2 are shown as 18 representative examples

Fig. 5 Acclimatization of guayusa plants. (a) Representation of the process used for data collection from 21 acclimatized plants. (b) Guayusa plant $30 \mathrm{~d}$ after acclimatization

23 Fig. 6 Shoot length of acclimated guayusa plants. Box plots represent the control and four light conditions, T1, 24 T2, T5, T6. Results are representative of four to six plants per treatment. (a) First day of acclimatization after $25180 \mathrm{~d}$ of growth. (b) 30 days after the beginning of acclimatization. Letters denote significantly different values 26 (one-way ANOVA, $p<0.05$ ) 
1 Fig. 7 Leaf area of acclimated guayusa plants. Box plots represent the control and four light conditions, T1, T2,

2 T5, T6. Results are representative of four to six plants per treatment. (a) First day of acclimatization after $180 \mathrm{~d}$ 3 of growth. (b) 30 days after the beginning of acclimatization. Letters denote significantly different values (one4 way ANOVA, $p<0.05)$

6 Fig. 8 Root development of acclimated guayusa plants that rooted spontaneously after 180 d. Box plots represent 7 the control and four light conditions, T1, T2, T5, T6. Results are representative of four to six plants per treatment.

8 (a) Number of main roots. (b) Number of secondary roots. Letters denote significantly different values (one-way $9 \quad$ ANOVA, $p<0.05)$

10

11 Fig. 9 Root length of acclimated guayusa plants that rooted spontaneously after $180 \mathrm{~d}$. Box plots represent the 12 control and four light conditions, T1, T2, T5, T6. Results are representative of four to six plants per treatment. 13 (a) Main roots. (b) Secondary roots. Letters denote significantly different values (one-way ANOVA, $p<0.05$ ) 
Figures

2

3

Fig. 1

a

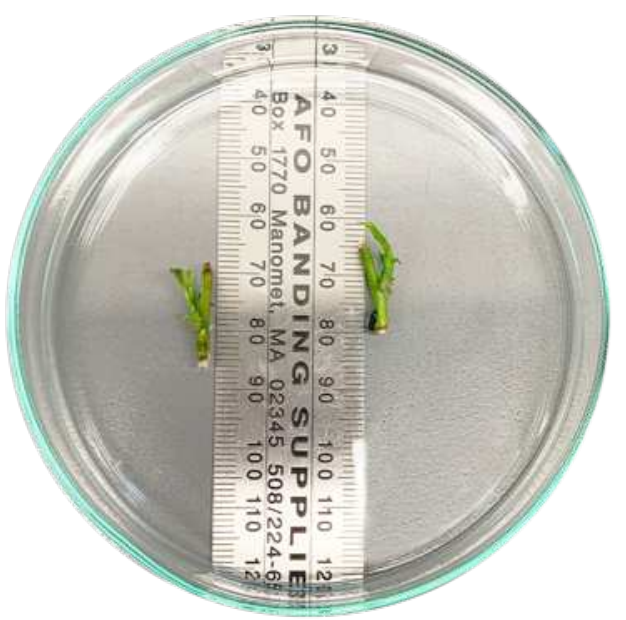

C

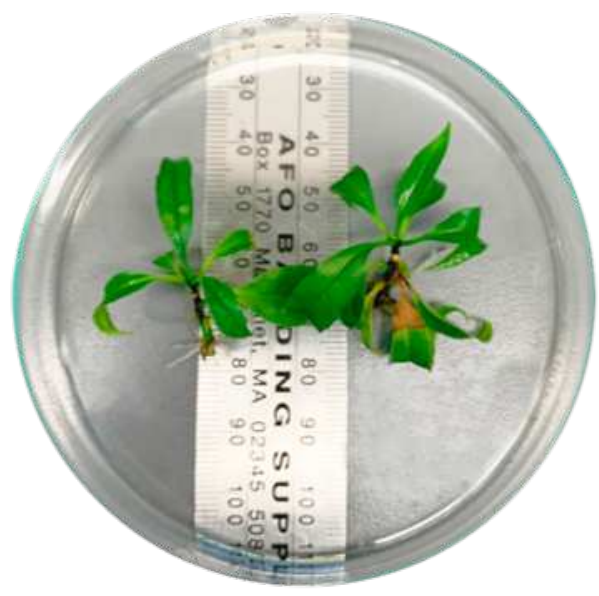

b

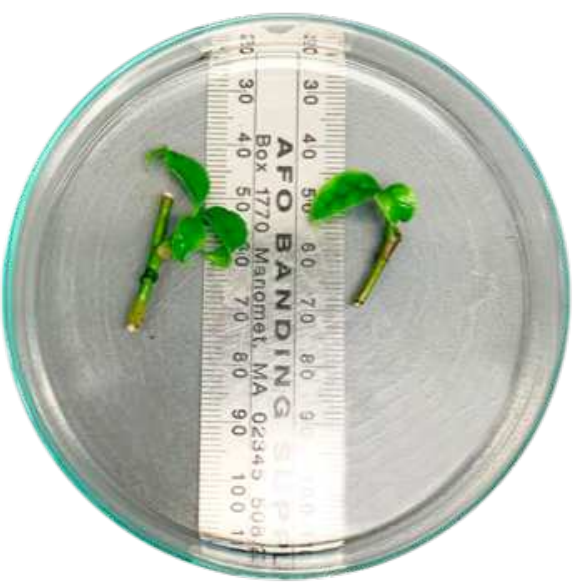

d

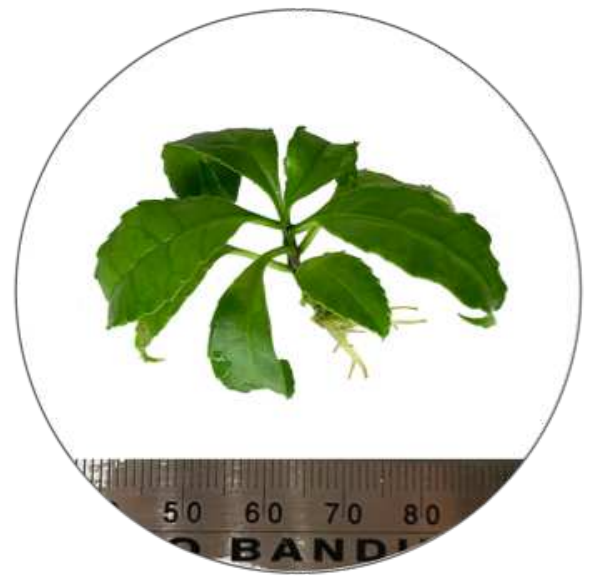


$1 \quad$ Fig. 2

a

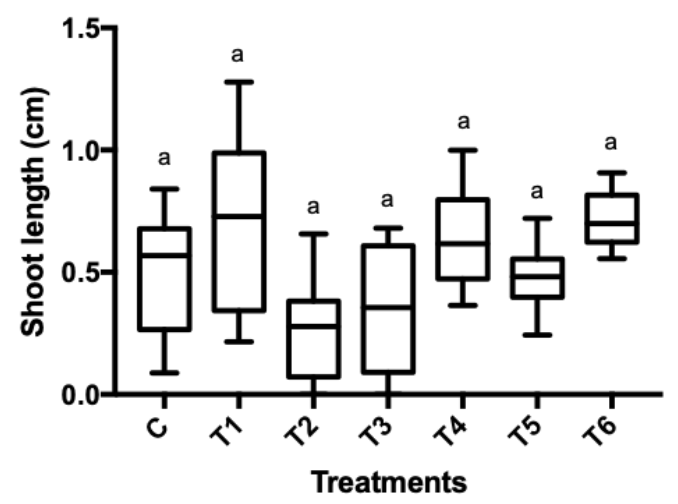

C

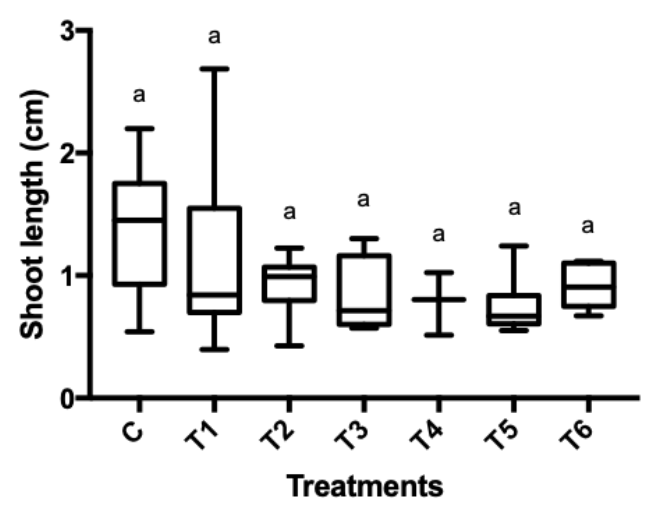

b

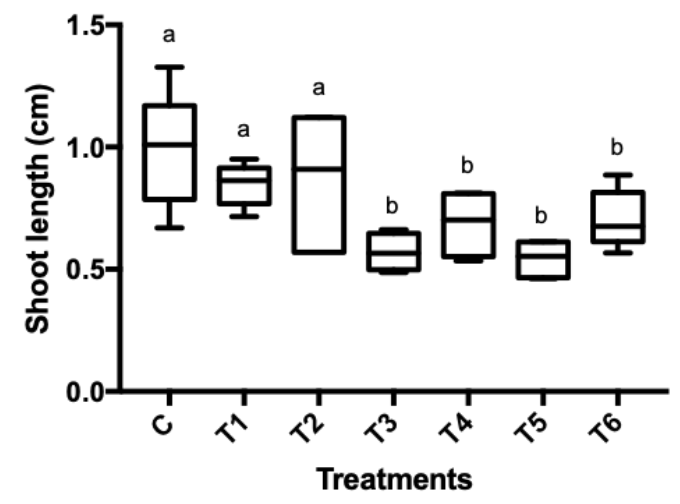

d

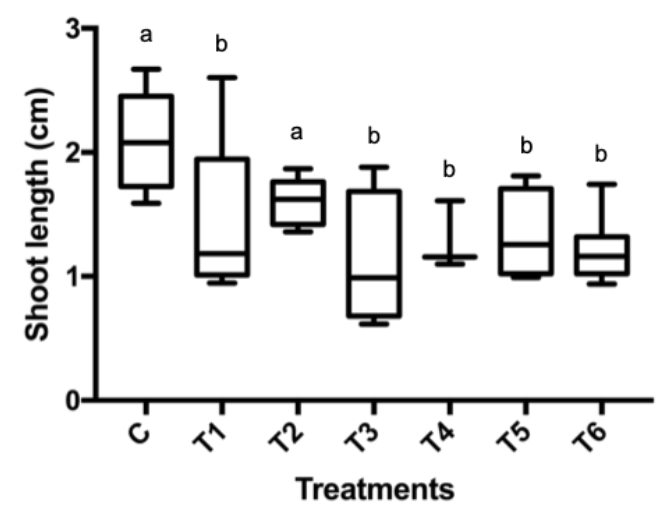


$1 \quad$ Fig. 3

a

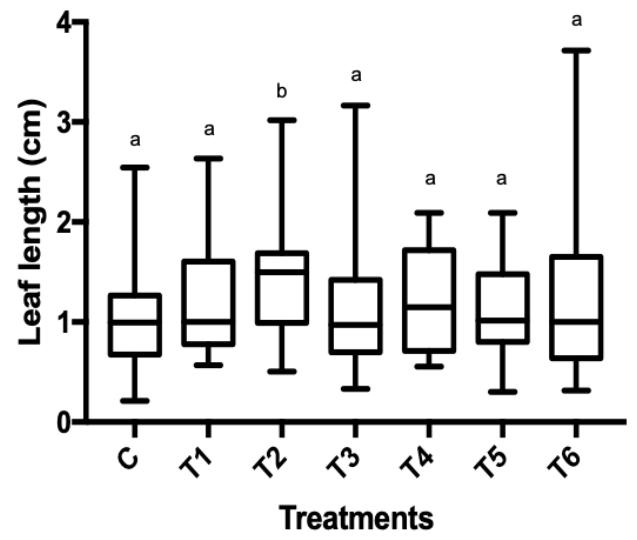

b

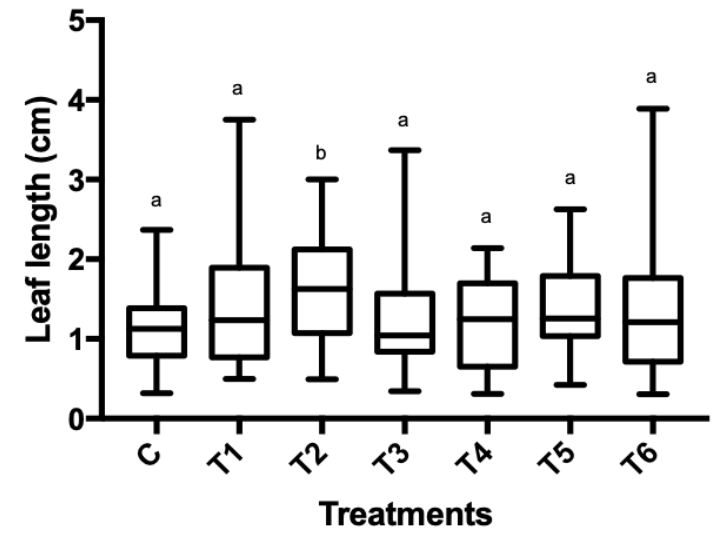

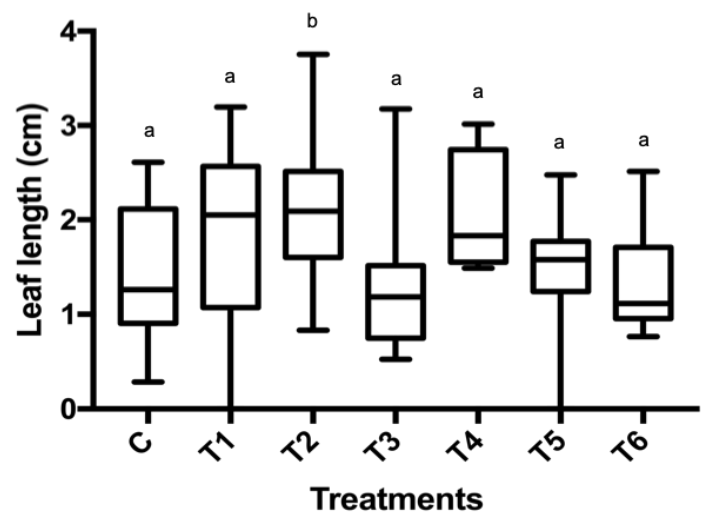


1 Fig. 4

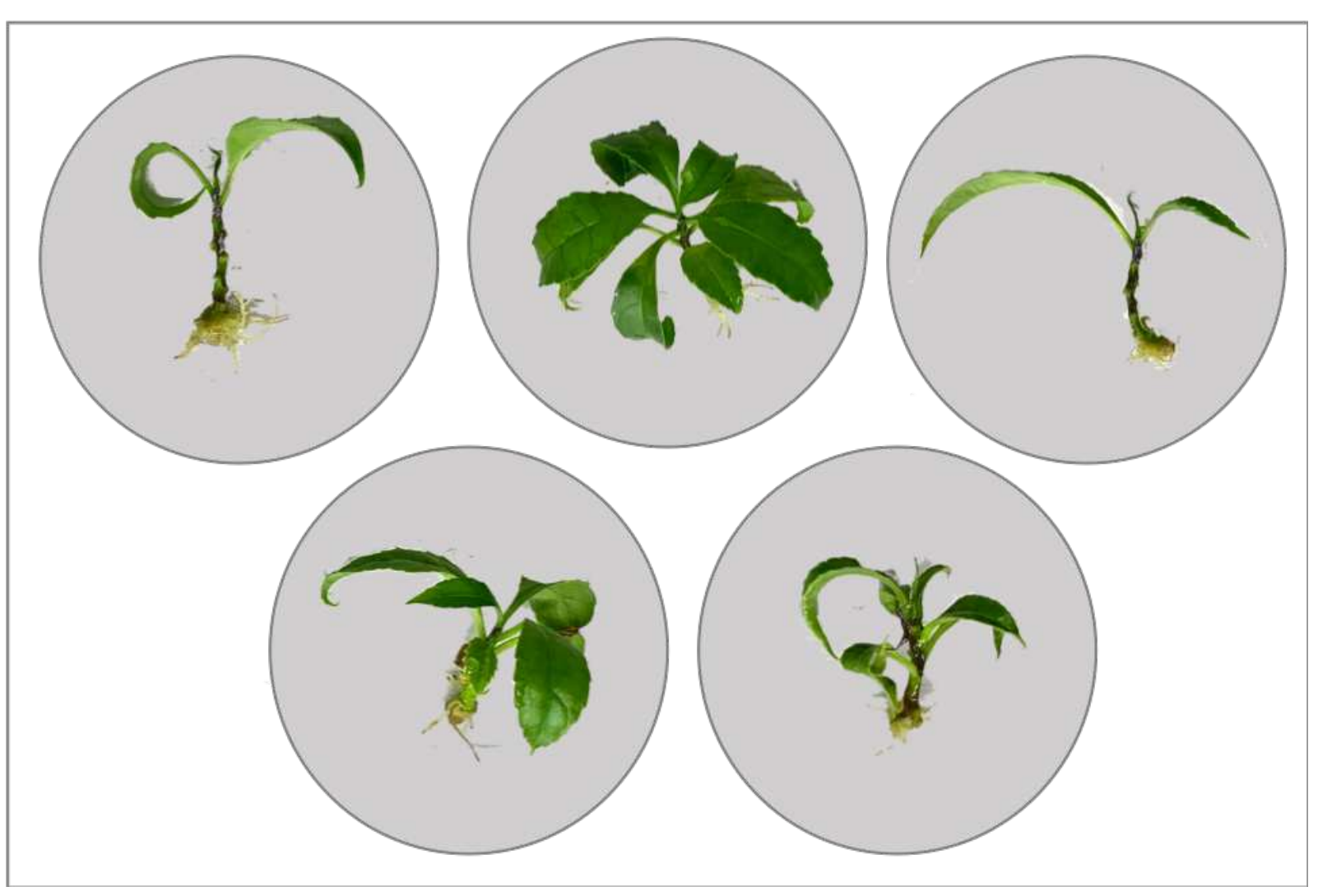


1 Fig. 5

a

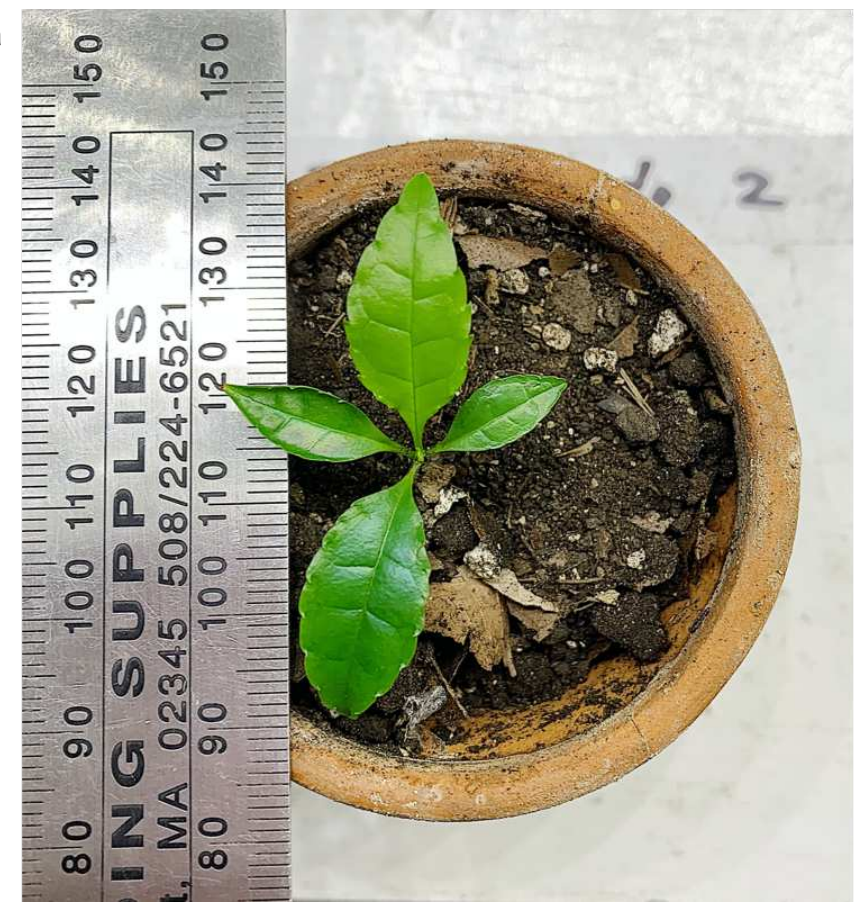

b

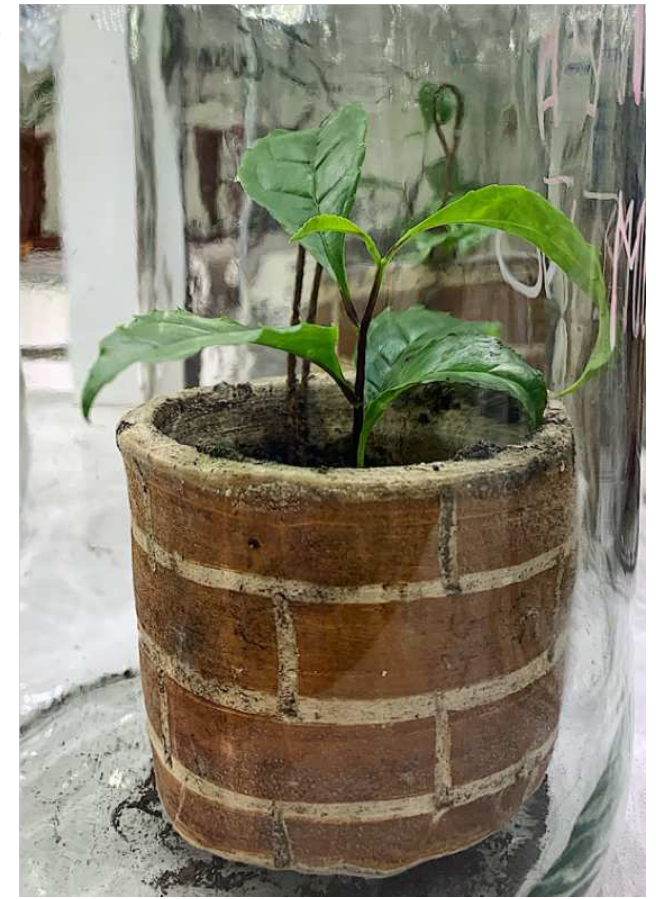


Fig. 6

a

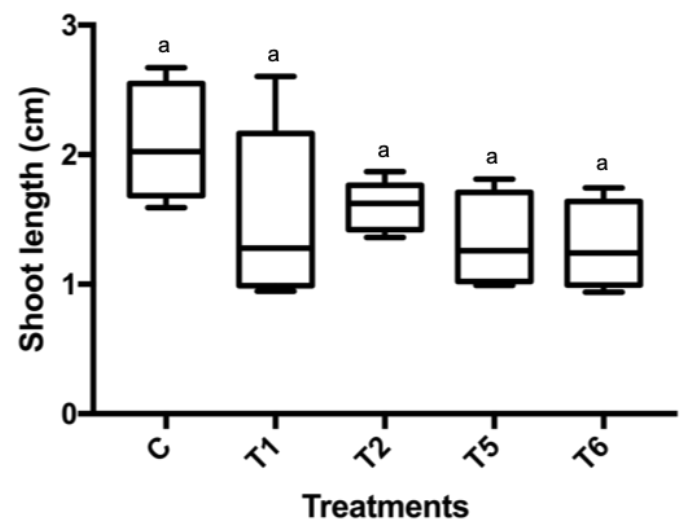

b

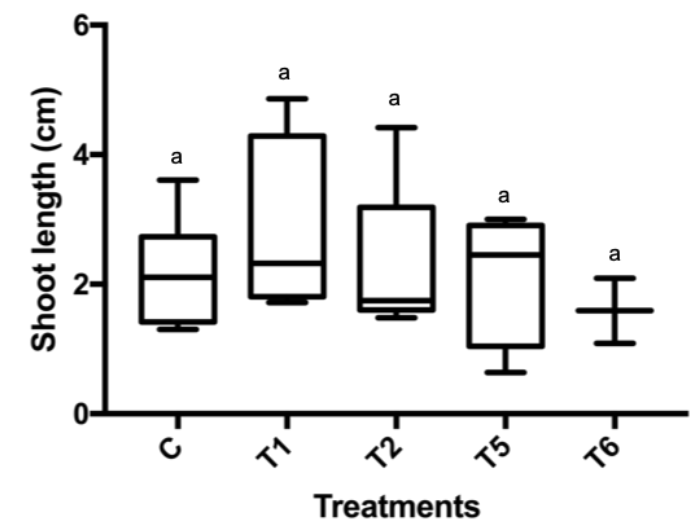


Fig. 7

2
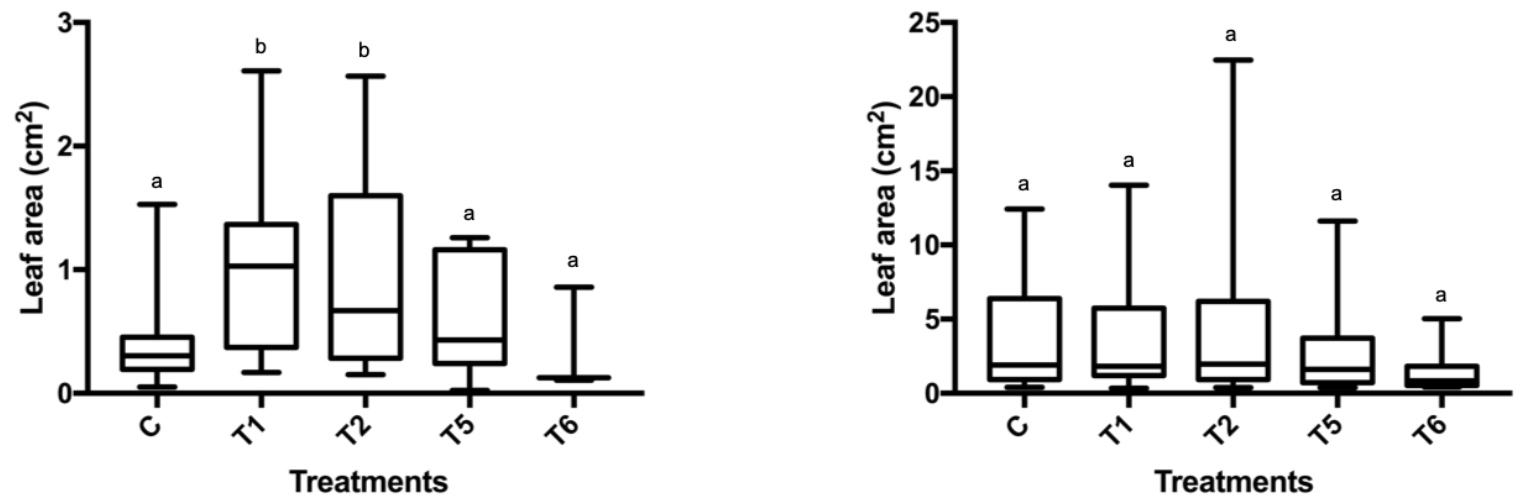
1 Fig. 8

a

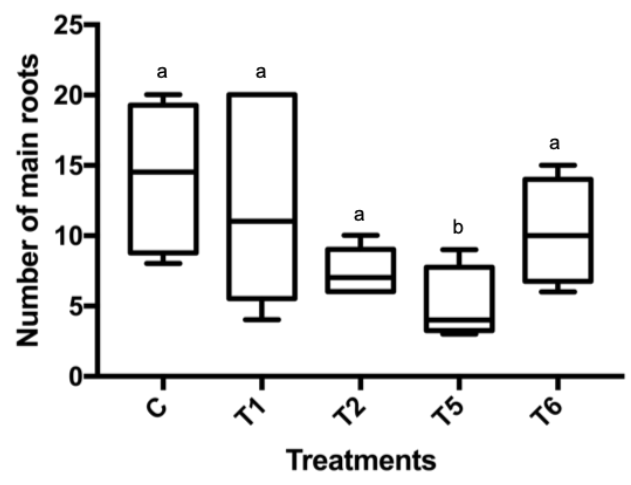

b

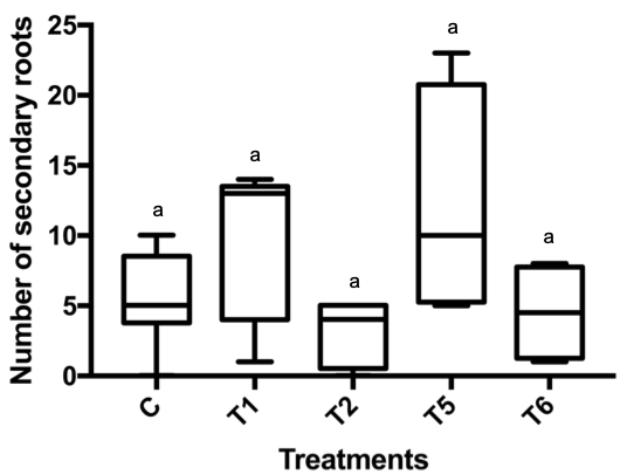


Fig. 9

a

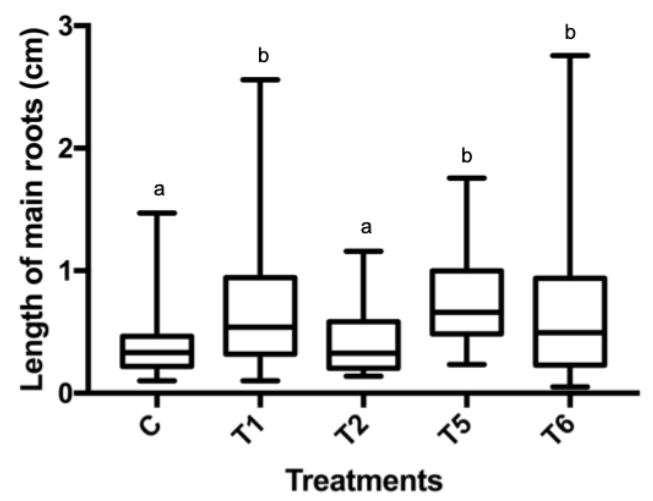

b

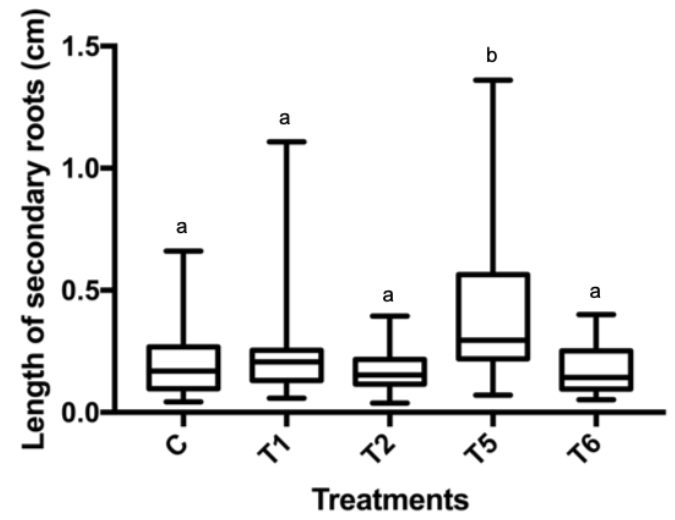




\section{Figures}
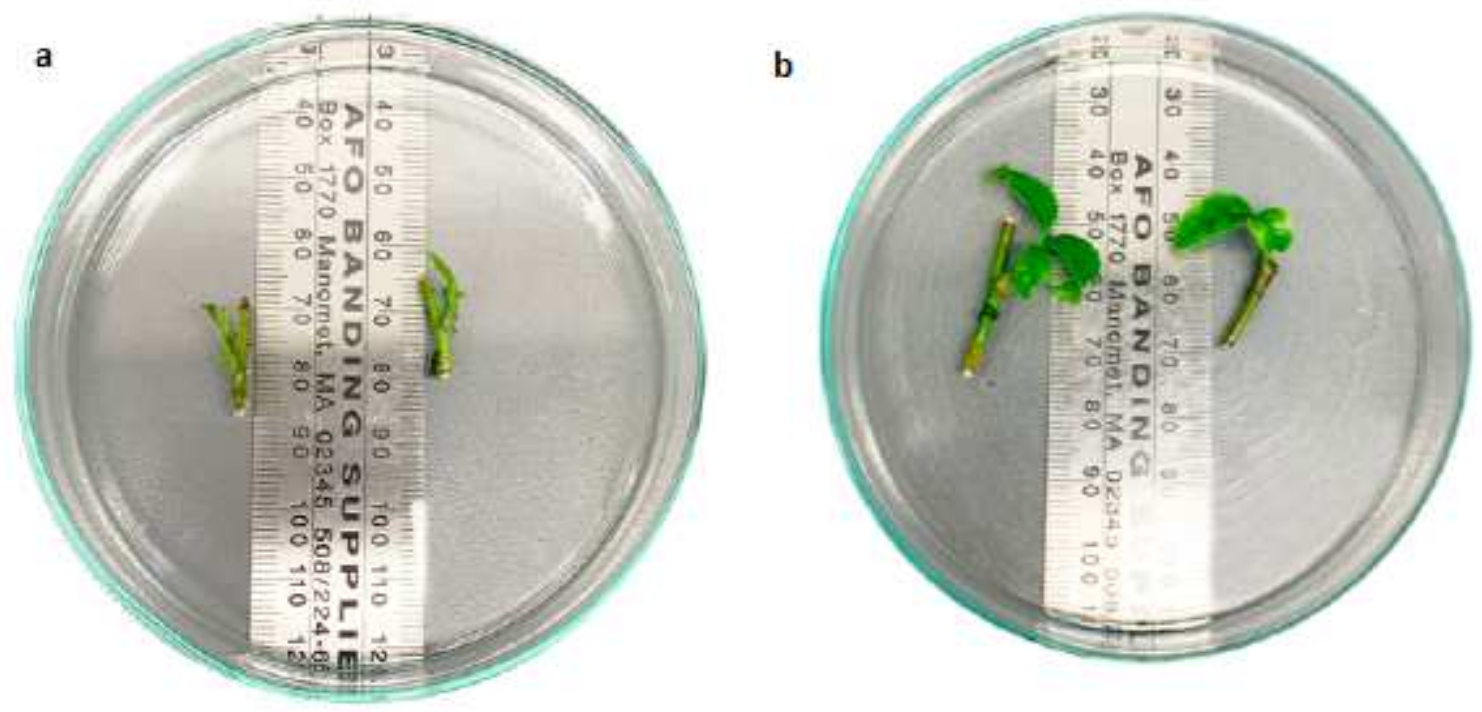

C

d
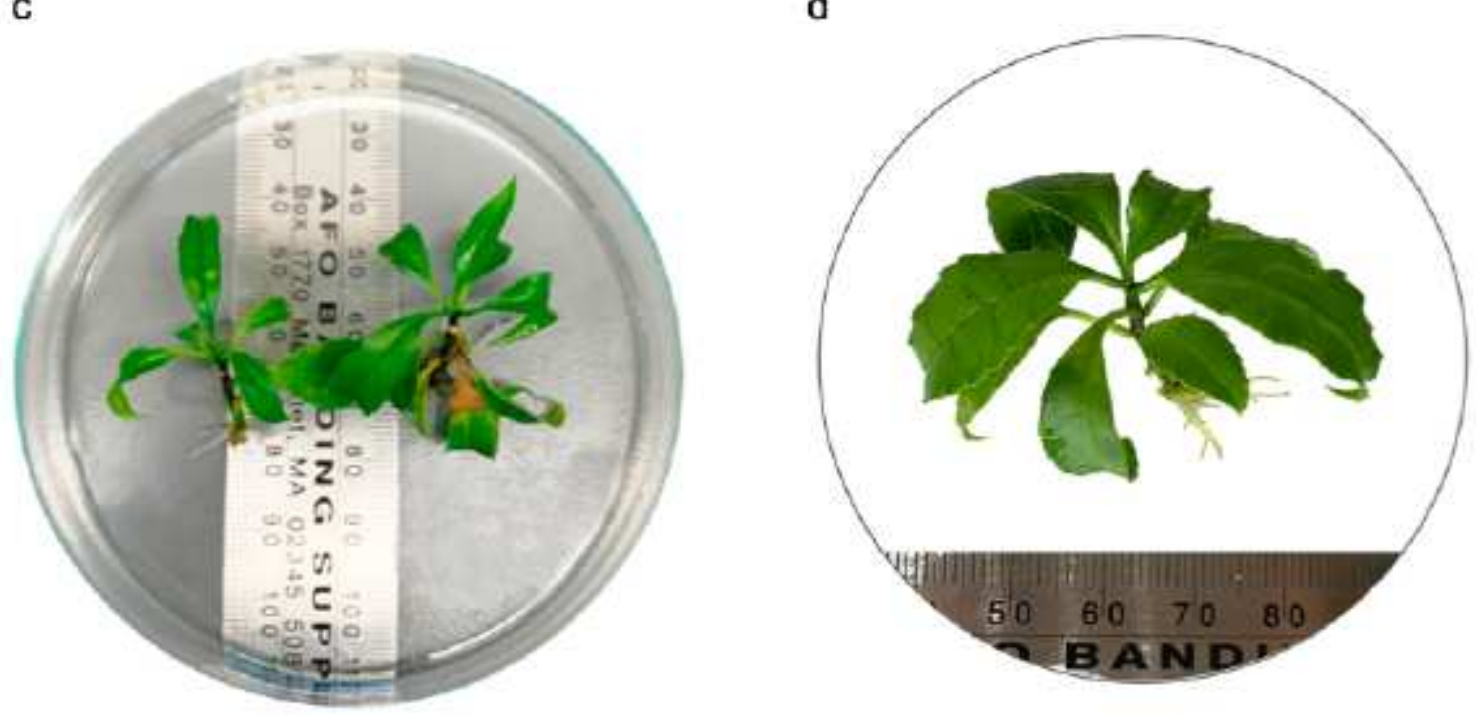

Figure 1

In vitro propagation of guayusa from axillary buds using stakes as initial material. Cuttings grown in mWPM + AC medium and exposed to light treatment T2 are shown as representative examples. (a) Developing bud on a stake. (b) $30 \mathrm{~d}$-old shoots ready to be separated from the stake. (c) Shoots after 150 d. (d) Developed roots in 180 d-old shoots 

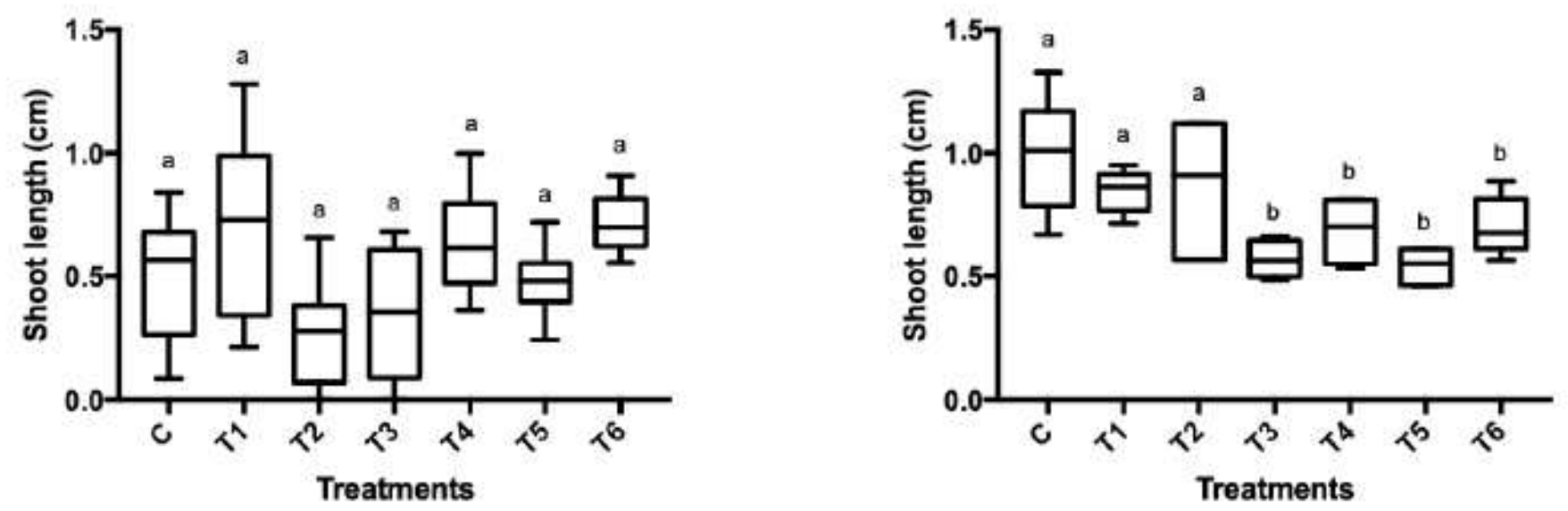

c

d
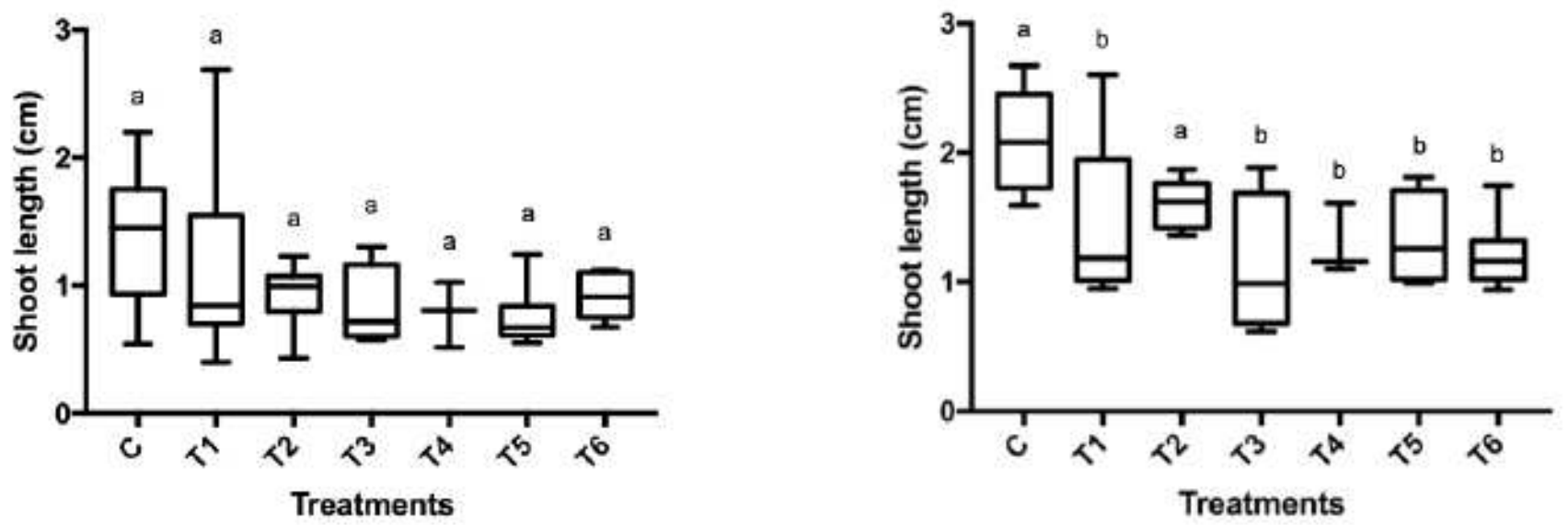

Figure 2

Shoot length in four subcultures. Box plots represent the control and six light conditions, T1 to T6. Results are representative of seven to eight plants per condition. (a) First subculture, $30 \mathrm{~d}$. (b) Second subculture, 90 d. (c) Third subculture, 150 d. (d) Fourth subculture, $180 \mathrm{~d}$. Letters denote significantly different values (one-way ANOVA, $p<0.05$ ) 

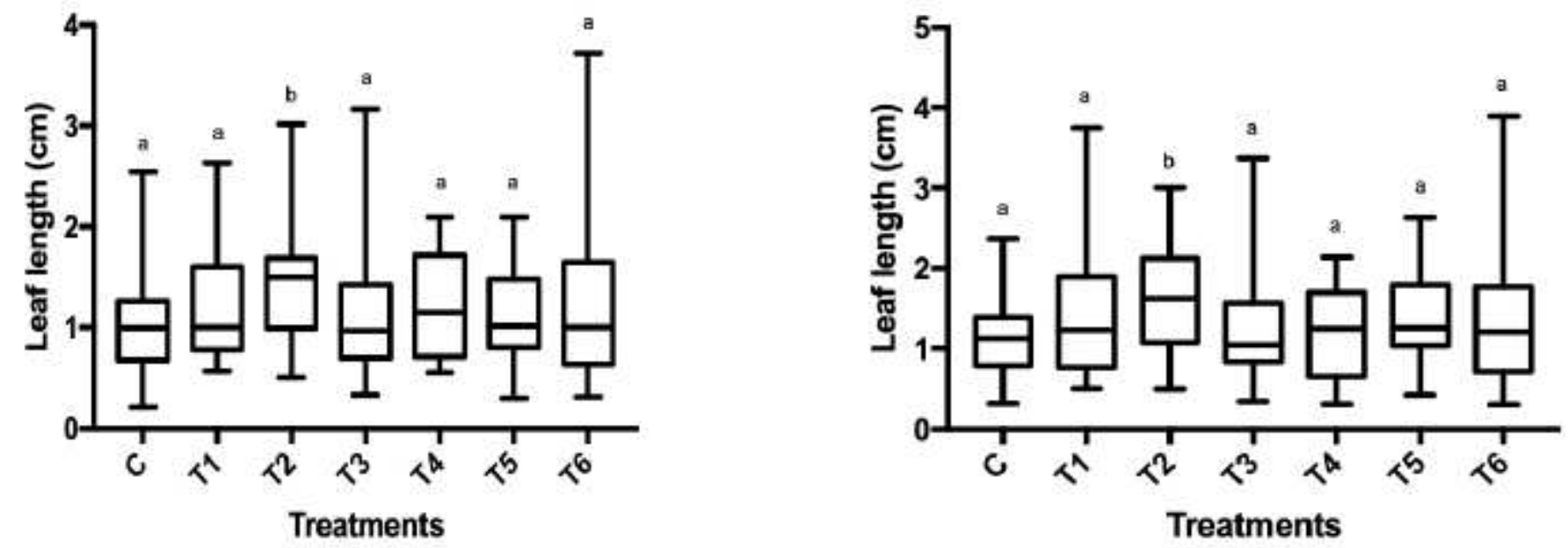

c

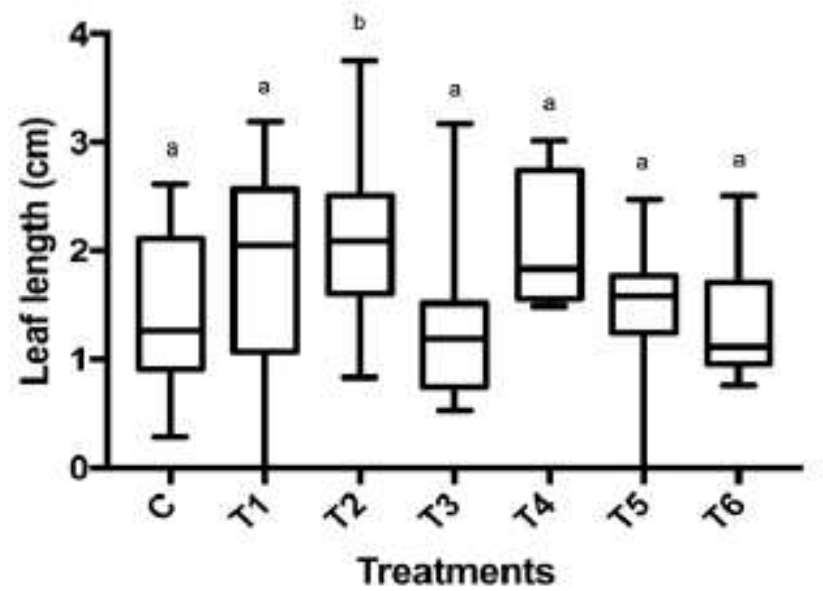

Figure 3

Leaf length in three subcultures. Box plots represent the control and six light conditions, T1 to T6. Results are representative of seven to eight plants per treatment. (a) Second subculture, $90 \mathrm{~d}$. (b) Third subculture, $150 \mathrm{~d}$. (c) Fourth subculture, $180 \mathrm{~d}$. Letters denote significantly different values (one-way ANOVA, $p<0.05)$ 


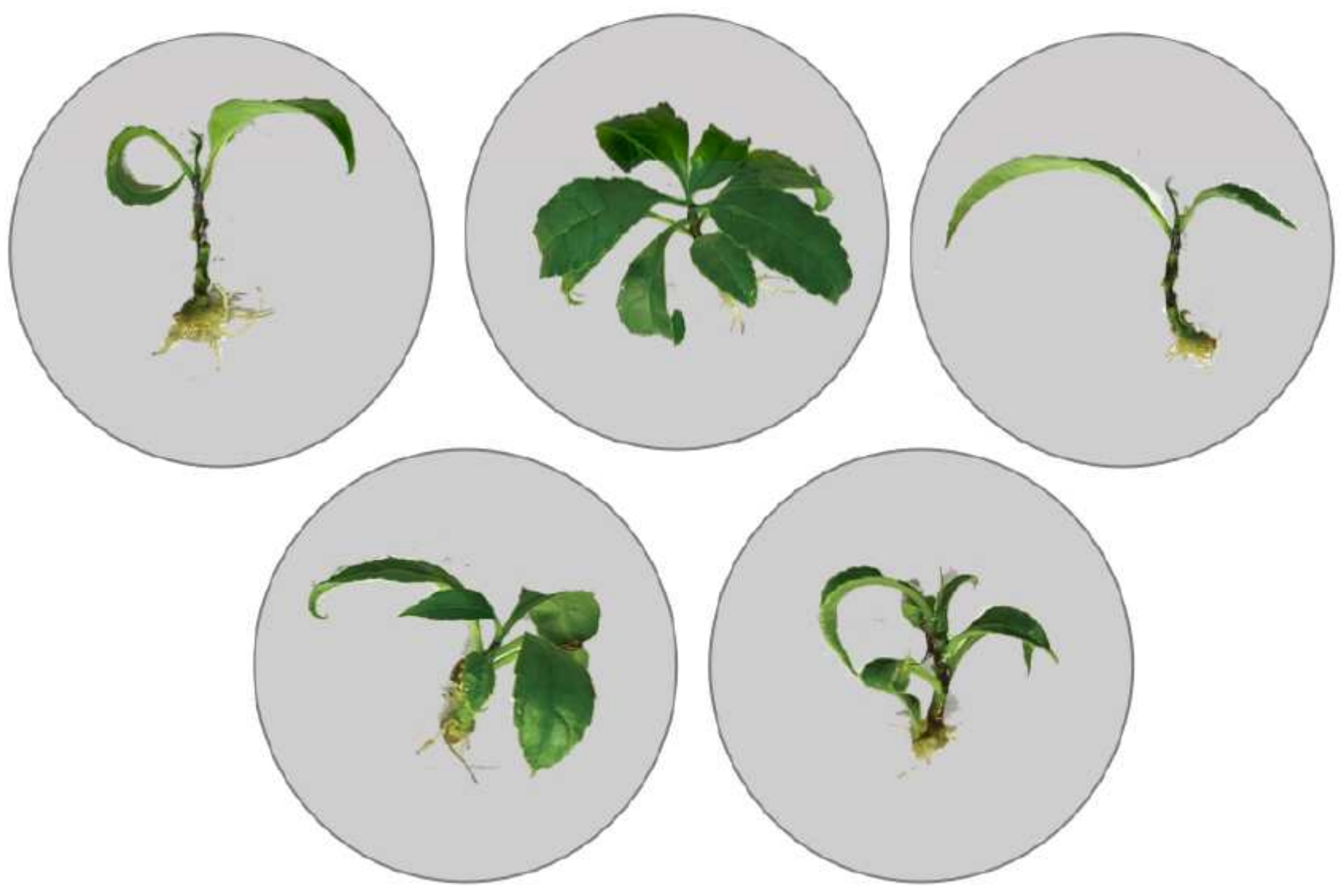

Figure 4

Spontaneous root development after $180 \mathrm{~d}$. Five plantlets grown under light treatment T2 are shown as representative examples 

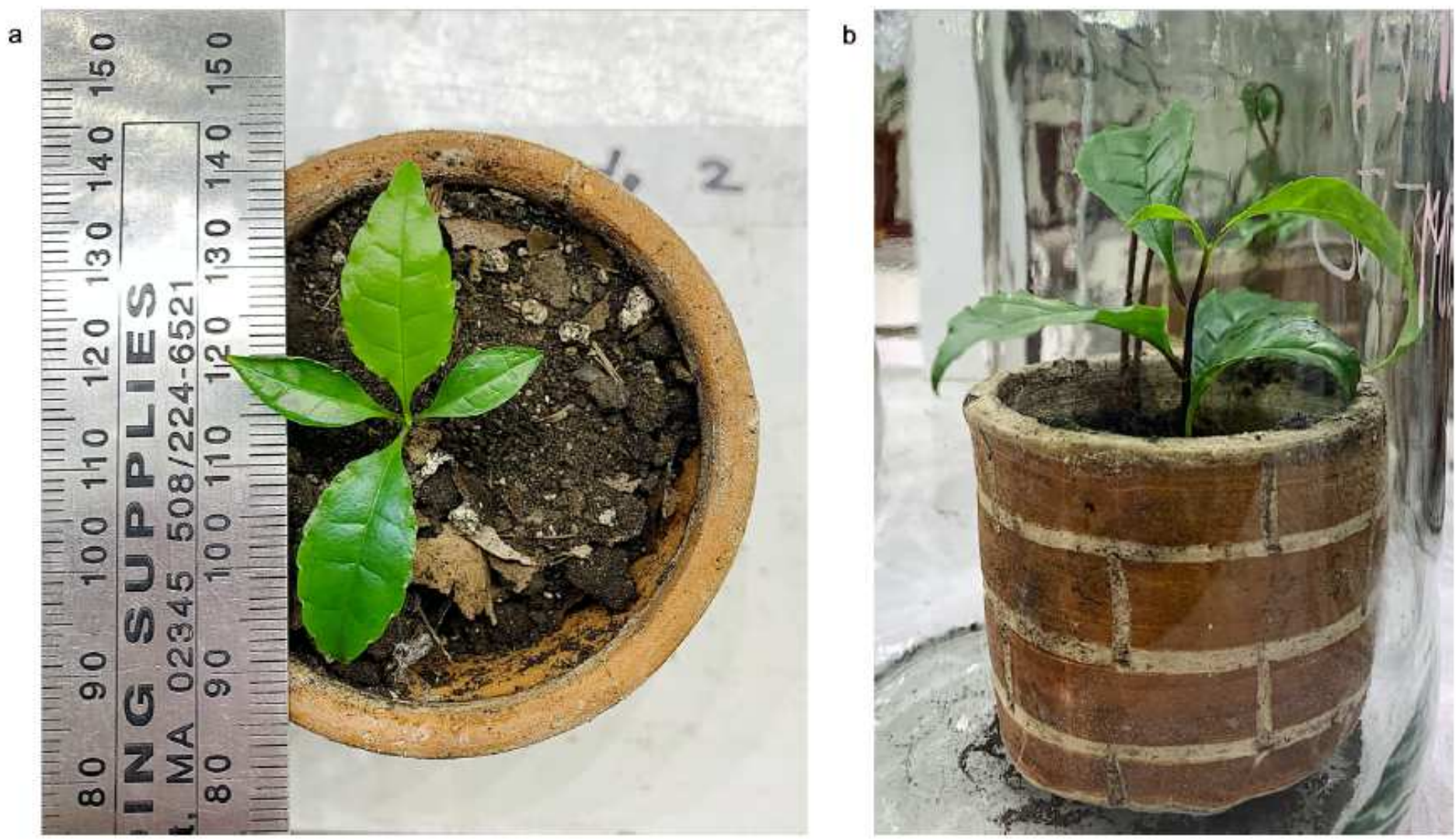

\section{Figure 5}

Acclimatization of guayusa plants. (a) Representation of the process used for data collection from acclimatized plants. (b) Guayusa plant $30 \mathrm{~d}$ after acclimatization

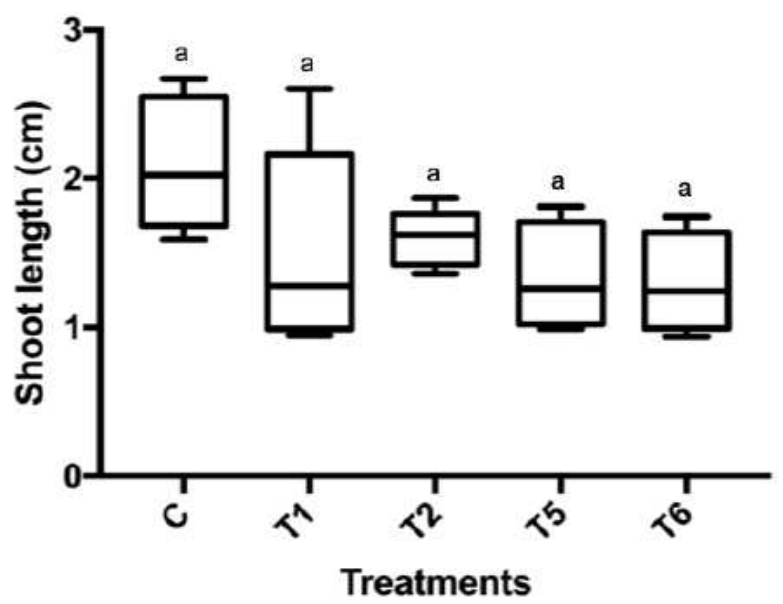

b

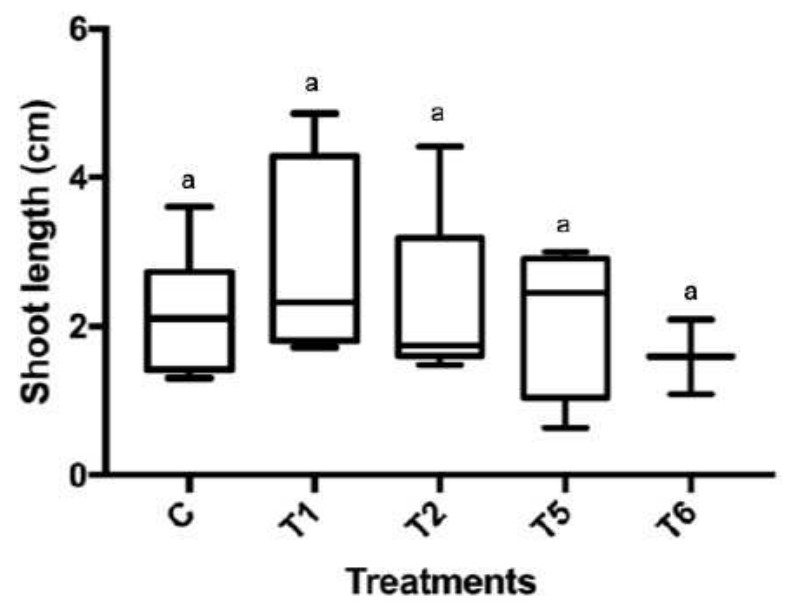

\section{Figure 6}

Shoot length of acclimated guayusa plants. Box plots represent the control and four light conditions, T1, $\mathrm{T} 2, \mathrm{~T} 5, \mathrm{~T} 6$. Results are representative of four to six plants per treatment. (a) First day of acclimatization 
after $180 \mathrm{~d}$ of growth. (b) 30 days after the beginning of acclimatization. Letters denote significantly different values (one-way ANOVA, $p<0.05$ )

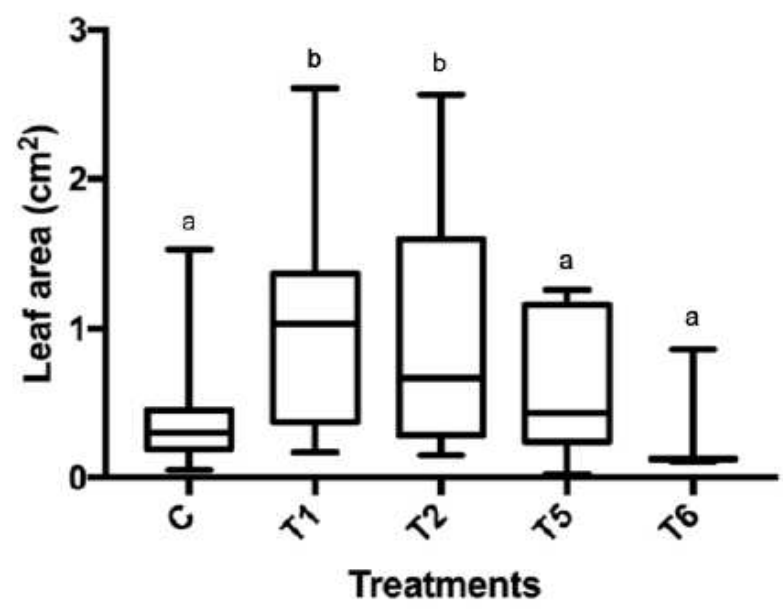

b

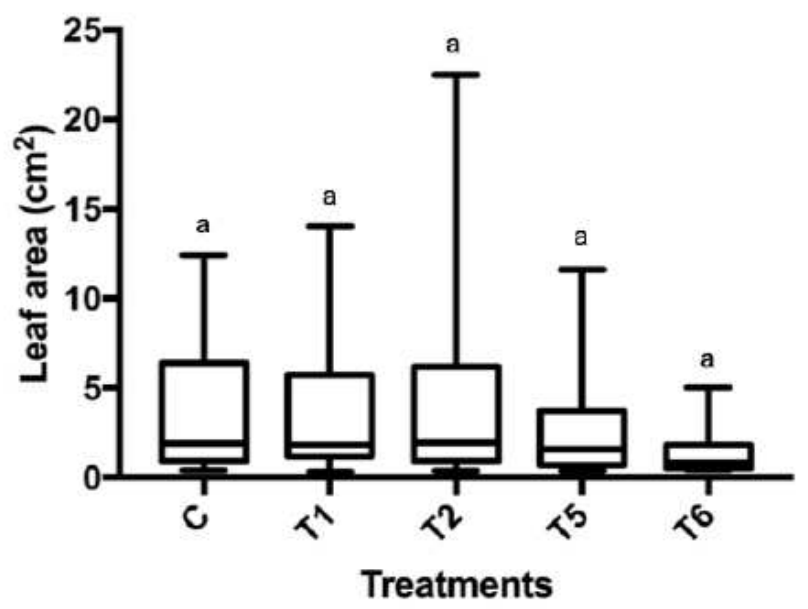

Figure 7

Leaf area of acclimated guayusa plants. Box plots represent the control and four light conditions, T1, T2, T5, T6. Results are representative of four to six plants per treatment. (a) First day of acclimatization after $180 \mathrm{~d}$ of growth. (b) 30 days after the beginning of acclimatization. Letters denote significantly different values (one way ANOVA, $p<0.05$ )

a

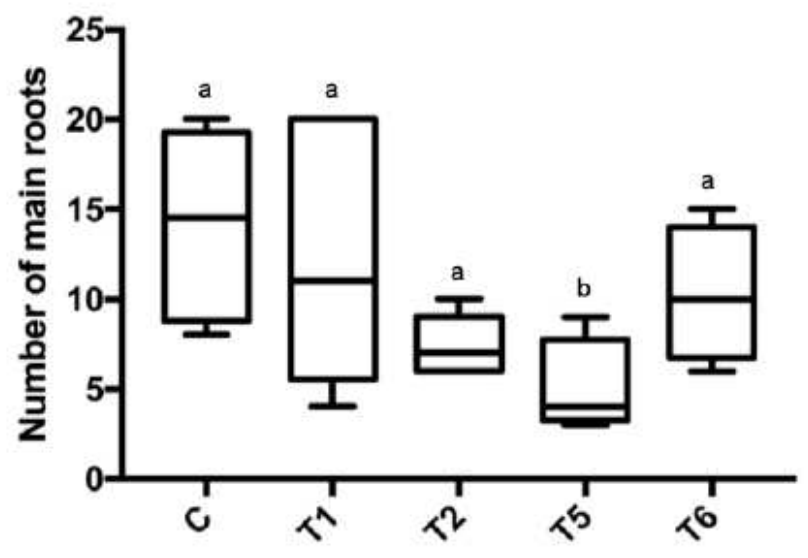

Treatments

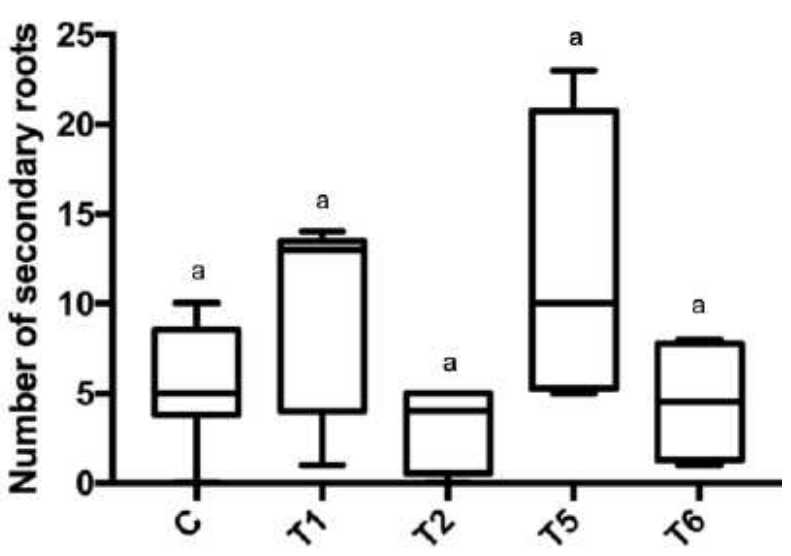

Treatments

Figure 8

Root development of acclimated guayusa plants that rooted spontaneously after $180 \mathrm{~d}$. Box plots represent the control and four light conditions, $\mathrm{T} 1, \mathrm{~T} 2, \mathrm{~T} 5, \mathrm{~T} 6$. Results are representative of four to six plants per treatment. (a) Number of main roots. (b) Number of secondary roots. Letters denote significantly different values (one-way ANOVA, $p<0.05$ ) 


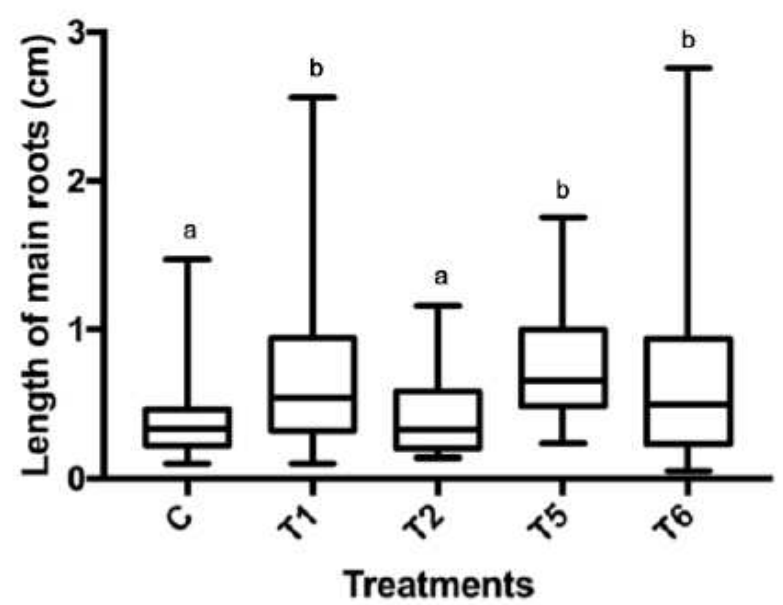

b

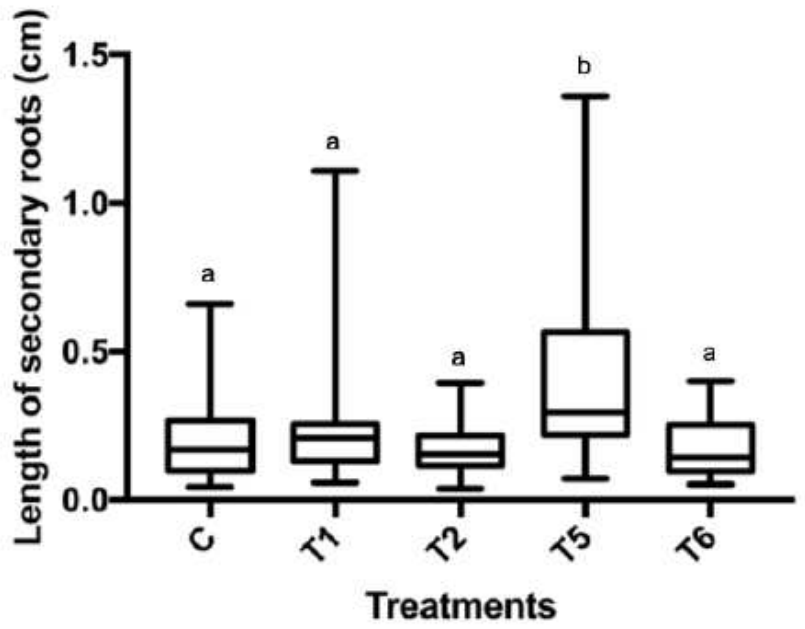

Figure 9

Root length of acclimated guayusa plants that rooted spontaneously after $180 \mathrm{~d}$. Box plots represent the control and four light conditions, T1, T2, T5, T6. Results are representative of four to six plants per treatment. (a) Main roots. (b) Secondary roots. Letters denote significantly different values (one-way ANOVA, $p<0.05)$

\section{Supplementary Files}

This is a list of supplementary files associated with this preprint. Click to download.

- GuayusaSI.pdf 